\title{
ÇİTE VATANDAŞLIK
}

Prof. Dr. Erdoğan G̈̈ĞER*

\section{I. ÇIFTE VATANDAŞLIK KAVRAMI}

Vatandaşlık birey ile Devlet arasında öyle bir bağ oluş̧urmakta ki, buna dayanarak Deviet, kişiye siyasî koruma sağlar, ulusal mahkemelerin yetkisini ülke dışına yayar ve nihayet bireye hak ve yükümler getiren bir hukukî statii verir. Uluslararası siyasi koruma, uygulamada diplomatik koruma (diplomatik himaye) yöntemiyle olmakta ve millileştirme, kamulaştırma ve özel vergi tahsili gibi ekonomik konularda, çoğunlukla kendisini göstermektedir. Diplomatik koruma, savaş halinde savaşan Devletler vatandaşlan açısından önemini büyük ölçüde yitirmektedir. Vesayet, manda, kapitülasyon gibi özel kurumların varlığı halinde, diplomatik koruma kapsam değiştirmektedir. Diplomatik koruma, NATO, Birleşmiş Milletler gibi uluslararası örgütlerin ülkede bulunan personeli açısından yürürlükte olan özel andlaşmalar hükümlerine tâbidir. Bu konuda, "Birleşmiş Milletler Andlaşması" San Francisco, 26 Haziran 1945, md. 104 ve 105 örnektir.

Devletin egemenliğine dayanan yargılama yetkisi ülkeseldir. Türk mahkemelerinin yargı hakkı Devletin coğrafi sınırları ile bağıdır. Mahkemelerin yargı hakkının ülke sınırlarımı aşarak, yabancı ülkelerde cereyan eden hukukî olayları, uluslararası hukukun ilkelerine uygun olarak, yargı yetkileri içinde görmeleri olasılıdır. Bu olasılık ulusal Devletin yasal hükümlerinden veya andlaşmalardan doğabilir. Yargı yetkisinin ulusal coğrafi sınırları aşmasının örneklerine, Osmanlı Devletinde önemli yeri olan Kapitülasyonlarda da rastlanmaktadır. İç hukuktan örnek, Ceza Muhakemeleri Usulü Yasası md. 10 'da düzenlenmiş olan yabancı memleketlerde işlenen suçlarda Türk yargısının yetkili olduğu halleri gösteren hükümdür. Türkiye'nin katıldığı, Uluslararası Hava Taşımalarına tlişkin Bazı

(*) Ankara Universitesi Hukuk Fakültesi Eski Öğretim Ûyesi, 
Kuralların Birleştirilmesi Hakkında Hava Sözleşmesi md.28, Uluslararası Sözleşmelere örnek olarak gösterilebilir. Yabancı öğeyi içeren dâvalarda ulusal mahkemelere yetki tanınmast da, uluslararası yetkinin bir parçasıdır. 2675 sayılı DHH yasası $(20.5 .1982$ tarih ve 2675 sayılı Milletlerarası Özel Hukuk ve Usul Hukuku Hakkında Kanun) İkinci Kısım, Birinci Bölümünde Türk mahkemelerinin uluslararası yetkisini dïzenlemektedir.

Devletin egemenlik hakkına dayanarak birey ile arasında kurduğu bağın hukukî yönü de vardır. Vatandaş olan birey, Devletin egemenlik hakkına dayanarak koyduğu yasaların tanıdığı haklardan yararlanmakta ve aynı yasaların getirdiği yükümlere tâbi tutulmakta. Devletin koyduğu Anayasa, bir yandan Devletin yapısınt ve örgïtleriyle bunların işleyişini gösterir, diğer yandan bireyin hak ve yükümlerinin temelini oluşturan sınırları çizer. Yasalarla ayrıntıları düzenlenen bu hak ve yüküimlerin tümï vatandaşlık bağının bir hukukî statüyü de kapsadığını göstermektedir. Bağımsız üniter Devletlerde vatandaşlar arasında hukukî statü eşitliği kuraldır. Ingiltere gibi Devletlerde, sömürge ahalisi ile anavatan halkı arasında hukukî statü eşitliği görecelidir. Osmanlı Devletinde de, zımnî (reaya), müslüman tebaa ve koruma altındaki tebaa ayrı ayn hukukî statüleri olan kategorilerdir. Hukukî statülerin içeriğini saptayan mevzuat ta birbirinden farklıdır. Örneğin müslüman tebaa şeriat hükümlerine tâbi olduğu halde, himaye altındaki tebaa yabancı Devletlerle imzalanmış andlaşma hükümlerine tâbidir. Hukukî statï farkı Federal Devlet sisteminde de ortaya çıkabilmektedir. Çifte vatandaşlik bireye, iki ayrı Devletin hukukî statii tanıması, mahkemelerinin uluslararası yetkisine tâbi tutması ve diplomatik koruma sağlaması haline denir.

Üniter bağımsız Devletler, yukarıda yer alan ve hukukî statii farkından hareket edenden daha basit bir tanıma itibar etmektedirler. Bunun temel nedenlerinden birisi, üniter Devletlerde, vatandaşlar arasında hukukî statti eşitliğidir. Ahali, din, dil, ırk ölçütlerinden birisine dayanarak farklı hak ve yükümleri olan kategorilere ayrılmamaktadır. Diğer temel neden, vatandaşlık hukuku ile mahkemelerin uluslararası yetkisi ve diplomatik koruma arasında ilişki kurulmamasıdır. Türk mahakemelerinin uluslararası yetkisi Uluslararası Usul Hukukunu, diplomatik koruma Devletler Hukukunu ilgilendirmektedir. Devlet egemenlik hakkına dayanarak, kendisini oluşturan ana öğelerden, ahaliden sayılma koşullarını vatandaşlık yasaları hükümlerine dayanarak saptamaktadır. Lâik Devlet 
dinî ve ırkî nedenlerden uzak olarak vatandas sayılma koşullarını hükme bağlar. Uluslararası teamül, andlaşmalar, vatandaşlik hukukunun genel ilkeleri egemenliğin sınırlarıdır. Aynı soya mensup olanların hepsini vatandaş saymak kural değildir. Üniter Devletlerin yeğlediği tanıma göre vatandaşlık, bireyi Devlete bağlayan hukukî ve siyasî bağdır. Bireylerin Devletler arasında dağılımı konusunda ekonomik, siyasî ve demografik nedenlerle fazla bencil davranan Devletler aynı bireyin birden çok vatandaşlık kazanmasına yol açmaktadır.

Çifte vatandaşlık, Borçlar Hukukunda yer alan hakların telâhu$\mathrm{ku}^{1}$ kurumunu andırmaktadır. Çifte vatandaşlığa, vatandaşlık haklarunın telâhuku da denilebilir. Vatandaşhık haklarının telâhukunda, iki ayn yasaya dayanan, birbirinden tamamen bağımsız oluşan iki ayn hukukî bağ vardır. Bireyin, vatandaşlık bağı ile kazandığı her iki hukukî statíye, Devletlerden herbirisinin uymasımı isteme hakkı bulunmaktadur. Temelde var olan benzerliğe rağmen, her iki kurum arasında farklar bulumaktadır. Hakların telâhukunda borçlu aynı kişi olabilmektedir. Vatandaşlık hukukunda, hukukî statii ayrı ayrı Devletler tarafından tanınmaktadır. Sonra, hakların telâhuku iki ayIl türe bölünmektedir. Telâhuk eden haklar iki ayn talep hakkundan veyahut iki ayrı yasa hükmünden doğmaktadır. Vatandaşlık hukukunda belirtilen ikili ayırım yoktur. Cünkü, mutalebe hakkından vatandaşlığın doğması söz konusu değildir. Kaldı ki, hakların telâhukunda haklardan birisinin kullanılması diğerini değersiz kılar. Vatandaşlık hukukunda haklardan birisinden yararlanmak, diğer vatandaşlık hakkını sona erdirmemektedir. Vatandaşlık hukukunda hakkın sona erişi bir idari tasarrufla olmaktadır.

Aynt bireye iki ayri Devletin vatandaşlik vermesi halinde vatandaşlık çatı̧mast (tâbiiyet ihtilâfı) vardır. Vatandaşlık çatışması ile yasaların çatışması (Kanunlar İhtilâfı) arasında fark bulunmaktadır. Yasaların çatışması, yabancı öğeyi içeren bir hukukî ilişkiye uygulanacak (madd̂̀) iç hukuk kurallarını aramaktadır. Edimli (fiili) bir hal olan vatandaşlık çatışmalarında, vatandaşlık bağına uygulanacak iç hukuk düzenlemesi aranmamaktadır. Her iki Devletle olan vatandaşlık bağlarının varlığı tartışmalı değildir. Her somut olayda, iki Devlet vatandaşlı̆̆ı arasından birisi, yargı̧̧ veya yetkili

1. Borçlar Hukukunda hakjarnn telâhuku konusu için bkz. Arsebük, Borçlar Hukuku, Ankara 1950, s.38-40. 
makam (kısaca lex fori) tarafından seçilmektedir. Bu seçim, tüm hukukî olgular hakkında geçerli olmayıp, somut olaya münhasırdır. Seçim sonucunda uygulanmayan vatandaşlık bağı sona ermemektedir. Vatandaş̧ık çatışmalarının konusu, somut olayla ilgisi bulunan bireyin sahip olduğu iki veya daha çok vatandaşlığı arasından seçim yaparak, vatandaşlıklardan birisine öncelik tanımaktadır. Yasaların çatışması alanında yetkili yasanın bulunabilmesi, çoğu kez bireyin vatandaşlı̆̆ının doğru olarak saptanmasına bağlıdır. Örneğin, 2675 sayılı DHH yasası, Türk DHH (Devlet Hususî HukukuDevletler Özel Hukuku) alanında ulusal yasa (millî kanun) bağlama kuralından hareket etmiştir. Ulusal yasa bağlama kuralının uygulanabilmesi, çifte vatandaşlığa sahip ilgilinin vatandaşlıkları arasından birisinin seçilmesine bağlıdır².

İnsanların derebeyler arasında paylaşturılması Feodal dönemde, üzerinde durulan sorunların başında gelmiştir. Feodal düzenin dayandığı ilke insan emeğinin sömürüsüdür. O dönemden kalmış olan bir ayırıma göre vatandaşlık çatışmaları olumlu ve olumsuz olmak üzere ikiye ayrılır. Bireyin, birden çok vatandaşlı̆̆ı olması haline olumlu çatışma, hiç vatandaşlığı olmaması haline olumsuz çatışma denilmektedir. Olumlu çatışmalar, endüstriyel toplumun gelişmesi ile varlığını kabul ettirmiş ve bu çatışmaların önlenemeyeceği inancı egemen olmuştur. Olumlu çatışmalar uluslararası gerginlik dönemlerinde, savaş devirlerinde ve sermaye ile emeğin ulusal sınır ötesine taşınması halinde, hiç de küçümsenemeyecek çekişmelere yol açmıştır. Çifte vatandaşlığın, feodal düzenin ortaya koymağa çalıştığı kadar korkulacak bir hal olmadığı endüstriyel toplum tarafindan kabul olunmuştur. Endüstriyel toplum düzeni, çifte vatandaşlığın, zararından çok yarar olduğuna inanmaktadır. Önce çifte vatandaşlık, çıkarlar dengesi alanında bireyin yararınadır. Birey, siyasî veya ekonomik nedenlerle ayrıldığı vatanından tamamen kopmamaktadır. Ayrıca, birey çifte vatandaşlık sayesinde kültürlerin biribirlerini anlamalarına yardımcı olmaktadır. Birey kültürler arasında köprü görevini yapmaktadır. Sonra, çifte vatandaşlık emeğin ve sermayenin dengesiz dağılımının getirdiği sakıncaları kısmen de olsa azaltmaktadır. Bir diğer nokta da, Devletin yabancı ülkelerde, ulusal çıkarlara hizmet edecek baskı gruplarını oluşturmasının kolaylaşabileceğidir. Kaldı ki, Türkiye gibi emek ihraç eden, hızlı nü-

2. Vatandaşıı hukuku ile yasalann çatışması arasındaki iliş̧kiler açısından bkz. Makarov, Allgemine Lehren des Staatsangehörikeitsrechts, 1947, s.62, ve s.170 vd. 
fus artışı dolayısıyla işsizlik sorunu bulunan ve yabancı sermaye ile yabancı teknolojiye gerek duyan ülkelerin çifte vatandaşlıktan korkmamalan gerekir.

2709 sayılı ve 7.11.1982 tarihli Anayasa'nin Yabancı Ülkelerde Çalışan Türk Vatandaşları başlığını taşıyan 62'inci maddesi hükmü, gerçekte çifte vatandaşlı̆̆ kollayan bir hükümdür. Devlet yabancı ülkede çalışan Türk vatandaşlarının aile birliğini, çocuklarının eğitimini, kültürel gereksinmelerini ve sosyal güvenliklerini sağlayacak önlemleri almakla yükümlüdür. Bu önlemlerin pratik olarak alınabilmesi ve işlerlik kazanabilmeleri için geniş ölçüde ikili sözleşmeler yapılması zorunludur. Bunun yanında, yurt dışında çalışanların anavatanla bağlarının korunmaşı için gereken önlemleri almak da Devletin bir başka yükümüdür. Özellikle bu sonuncu yükümün yerine getirilebilmesi, Devletin mevzuatında kolaştırıcı düzenlemeler yapması ve geniş bir hoşgörï ile sorunlara bakmasını gerektirir. Türk'ün anavatanla bağının devamlılığını să̆layan etmenlerden birisi de vatandaşlık bağıdır. Anavatana bağlılığın sürekliliğini sağlayacak önemli kurumlardan birisi de çifte vatandaşlıktır. Ayrıca sözï edilen 62'nci maddenin yalnızca yurt dışında çalışanlara yönelik olmasıs da hatalıdır. Madde yalnız çalışanları değil yabancı ülkede bulunan tüm vatandaşları kapsar biçimde yorumlanmalıdır. Yabancı ülkede oturan işsizler, sığınmacılar, emekliler, taşınmaz iradı veya diğer rant yolları ile geçimini sağlayıp oturanları da, 62'nci madde kapsamına almak gereklidir.

Anayasa'nın 66'ncı maddesi ve ona dayanan 403 sayli T.V.Y. (Türk Vatandaşlığı Kanunu) çifte vatandaşlığa açıktır. Yabancı ülkede bulunan Türke vatandaşlık veren Devlet, gerçekte onu asimile etmek niyetini taşımaktadır. Anayasa'nın 66'ncı maddesi hükmü özünde, yabancı Devletin bu niyetine karşı Türk Devletinin direnmesini istemektedir. Gerçek amacı, Türklerin yabancı Devletlerce assimilasyonunu önlemek olan maddenin olumlu sonuç verebilmesi, bireyin çıkarlanna ağırlık tanıyan yasalar çıkarılması ve T.V.Y. geliştirilmesi veya yeni tamamlayıcı yasalar, örneğin çifte vatandaşlık yasası gibi, yapılması ile mümkündür. 66'ncı maddenin "Türk Devletine vatandaşlık bağı ile bağlı herkes Türktür" hükmü anlaşıIması zor bir ifadeye sahiptir. Türkiye Cumhuriyeti Devleti vatandaşı olan bir musevinin Türk soyundan olduğu gibi bir izlenimi, maddenin yazılışı vermektedir. Hükmün yorumunda Türk kavramını soya bağlayan bir düşünceden hareket edilmemelidir. Gerçekte hüküm, Türkiye Cumhuriyetine vatandaşlık bağı ile bağlı 
olan herkes Devletin ahali öğesinin bir üyesidir, demek ister. Ancak, Anayasa yapmanın zorluğu hatalara yol açmaktadır.

\section{II. ÇIFTE VATANDAŞLIĞIN TÜRLERI}

Çifte vatandaşlığın türlerinin olup olmadı̆̆ı sorusu üzerinde de durulmak gereklidir. Soruya yanıt aranırken vatandaşlık kavramının içeriği göz önüne alınmalıdır. Vatandaşlığın içeriğ̣i Devletin yasalarında gösterilen vatandaş olabilme koşullarıdır. Vatandaş olabilmek için Devletin öngördüğüi koşullar vatandaş sayılmanın tek ölçütüidür. Kısaca, vatandaşlığın biçimsel içeriği temeldir.

Vatandaşlığın biçimsel içeriğinden hareket edilmesi halinde çifte vatandaşlığın türlerinden söz edilememelidir. Aynı bireyin iki ayn Devlet tarafından öngörülen vatandas olma kosullarını yerine getirmesi olasıdır. Çăgdaş Devlet vatandaşlar arasında hukukî statï eşitliğini uygulamaktadır. Aynı biçimde üilke'de bulunan yabancılar yönünden de hukukî statü eşitliği ilkedir. Vatandaşlık kavramı soy ve din ölçütlerinden anndığına göre çifte vatandaşlığın türlere ayrılmasını haklı kılan bir neden yoktur.

Biçimsel içerik yerine vatandaşlığın özdeksel içeriğinden (maddî muhtevasından) hareket edilmesi halinde ise, çifte vatandaşlığ̀n türleri olduğu göze çarpmaktadır. Bireyin vatandaşlığını saptarken biçimsel içerik kadar, vatandaşlığın özdeksel içeriği ve vatandaşı̆̆ın gerçekliği de unutulmamalıdır. Çifte vatandaşlık alanında vatandaşlığin özdeksel içeriği ile gerçekliği ilkesi de önem taşır. Aynı soya veya dine bağlı kişiye Devlet, siyasi ve ekonomik nedenlerle biçimsel vatandaşlığ 1 vermemekte, fakat biçimsel vatandaşlığı vermediği aynı kişiyi hukukî statï açısından vatandaş işlemine tâbi tutmaktadır. Bu yoldan ortaya çıkan çifte vatandaşlığın temelini, biçimsel ölçütler değil, özdeksel içerik ve gerçeklik illkesi ölçütleri oluşturmaktadır.

Özdeksel içerik ve gerçeklik ilkesi açısından konu incelenirse çifte vatandaşlığın türleri olduğu kolayca anlaşılmaktadır. Lâik Devlet dinî ve ırkî nedenlerle, yabancı Devlet vatandaşını kendi vatandaşına yakın veya eşit bir hukukî statiiye sahip kılmaktadır. Diğer yandan Devlet yurt dışına giden vatandaşları arasında var olması gereken hukukî statï eşitliğini de bozmaktadır.

Türk hukukunda, en azından 1980'li yıllardan başlıyarak çifte vatandaşlığın türlerinden söz etmek gereklidir. 2527 sayılı ve 
25.9.1981 tarihli Türk soyluların ülke'de çalışmalarını düzenleyen yasa, vatandaşı̆ı̆ın gerçekliği ilkesine dayanarak sui generis bir yabancı türü yaratmıştır. 1980'li yılların sonlannda ortaya çıkan Balkan'lardaki ve Ortadoğu'daki istikrarsızłık, Sovyetler Birliği'nin daĞlaması olayları Türkiye'yi ülke'ye göç eden yabancı olayı ile karşı karşıya bırakmıştır. Bu göçün sonuçlarını düzenlemek üzere 2527 sayılı yasanın daha geliş̧irilmiş değişik bir türünün hazırlandığı basında yer alan haberlerden anlaşılmaktadır.

Türk vatandaşlık hukuku değişen koşullar altında, geçmişte yer alan anlayışından ayrılarak, vatandaşlığın türleri olduğu konusuna eğilmek zorundadır.

\section{Düzenli Çifte Vatandaşlık}

Düzenli çifte vatandaşlık, bağımsız iki ayrı Devletin vatandaşlığa ilişkin yasalari hükümlerinden kaynaklanmaktadır. Bu hale yasal çifte vatandaşlik dahi denilebilir. fleriki bölümlerde yer alan incelemeler de aksine bir açıklama olmadığı sürece düzenli çifte vatandaşlıktan hareket edilmiştir.

Ius soli (toprak bağı) ilkesini benimseyen bir Devletin ïlkesinde doğan, ius sanguinis (kan bağı) kuralına dayanan Devlet vatandaşlaninın çocukları nesep yoluyla yasal çifte vatandaşlığa sahip olacaktır. Evlilik dışında yabancı ana ve Türk babadan olan ve doğumla anasının vatandaşlı̆̆ını alan çocuk, Türk baba tarafından tanınırsa 403 sayılı T.V.Y. md. 2/c'ye göre Türk vatandaşlı̆̆ını kazanarak çifte tâbiiyetli. olacaktır. Çok Vatandaşlik Hallerinin Azaltılmasına Ilişkin 1963 tarihli Strasbourg Konvansiyonu evlenme, telsik, tekrar iktisap yollanyla da düzenli çifte vatandaşlığın ortaya çıkabileceğinden hareket etmektedir.

\section{Göreceli (izafi) Çifte Vatandaşlık}

Göreceli çifte vatandaşlık halinde de, vatandaşlığı düzenleyen yasa hükïmlerinden doğan bir hal sözkonusudur. Göreceli çifte vatandaşlık, iki veya daha çok Devletin aynı toprak parçası üzerinde hak iddia etmeleri ve o topraklarda yaşayan insanlara vatandaşlık vermelerinden kaynaklanmaktadır. Konuyu aydınlatmak için Sar Bölgesi (Sar ülkesi-Sar Havzası) örnek olarak getirilecektir. Sar ekonomik yönden Fransa'ya bağlanmış, fakat siyasal bakımdan Almanya'dan ayrılmak suretiyle, Ikinci Dünya Savaşı sonunda özel bir statüye kavuşturulmuştur. Buna göre Sar, Franșa açisından ya- 
bancı bir ülke niteliğini korumuştur ${ }^{3}$. Almanya'nun üzerindeki egemenlik iddiasına rağmen, Sar ülkesi kendi vatandaşlık yasasını yapmıştır ${ }^{4}$. Sar ahalisi bu yasaya göre, Alman ve Fransız vatandaşlıklarından bağımsız Sar vatandaşı olmuşlardır. Almanya ise, Sar Bölgesinde yaşayanlan Alman saymağa devam etmiş ve kendilerine Alman pasaportu vermiştir. Bu örnekten görüildügüi üzere, değişik Devletlerin aynı topraklar ve bu topraklar üzerinde yaşayan insanlar karşısında egemenlik hakkını kullanmak istemeleri göreceli çifte vatandaşlığa yol açmaktadır. Düzenli çifte vatandaşlıkta, bireylerin yaşadığı topraklar bağımsız Devletlerin ülkesi olup, bu topraklar üzerinde ikinci bir Devletin egemenlik hakkı iddiası yoktur.

\section{3. Örtülü.(noksan) Çifte Vatandaşlk-Fiili Çifte Vatandaşlık}

Burada vatandaşlık yasalan uygulaması sonucunda ortaya çıkmış bir çifte vatandaşlık söz konusu değildir. Kişi gerçekte tek bir vatandaşlığa sahiptir. Ancak, dinsel veya ırkî nedenlerle kişi bir ikinci ülke tarafından vatandaş gibi işlem görmekte veya vatandaşa temsil edilmektedir.

Fiilî çifte vatandaşlık haline 2527 sayılı, 25.9 .1981 tarihli, Türk Soylu Yabancıların Türkiye'de Meslek ve Sanatlarınt Serbestçe Yapabilmelerine, Kamu, Özel Kuruluş ve İşyerlerinde Çalışabilmelerine İlişkin yasa bir örnek oluşturmaktadır. Türk soylunun, 2527 sayılı yasadan yararlanabilmesi için çalışma izin belgesi alması gereklidir (md.3). Izin belgesi alan Türk soylu yabancı, çalışma hayatını düzenleyen yasaların hükümlerine tâbidir (md.5). Çalışma belgesi alan birey ülkede ikamet ve çalışmayı düzenleyen yasaların aradığı Türk vatandaşı olma koşulundan istisnadır. Kısaca, Türk soylu çalışma belgesi ile çalışma ve ikamete giren konularda Vatandaşla eşit durumdadır. Bu yasanın amacı, halen Türkiye Cumhuriyeti ülkesinden sayılmayan, eski Osmanlı topraklarında bulunan Türk soyluları korumaktır.

3. Sar ülkesinin ulusłararası durumu hakkında, tarihi bilgileri de içeren açıklama için bkz. Çelik, Milletlerarası Hukuk, Cilt I, İstanbul 1980, s.408-410. Aynca, benzer durum gösteren Danzig ve diğer ơrnekler için ayn eser s.407-412'ye bkz.

4. Sar ülkesinde değişik vatandaşlık yasalarının uygulanması, bundan doğan sorunlar ve ius soli ilkesinin sorunun çözüimünde oynadığı rol hakkunda aynntılı bilgi için bkz. Schaetzel, Das deutsche Staatsangehörigkeitsrecht, 2. Aufl. Berlin 1958, s.114122 ve aynca Elsass-Lothringen örneği için aynı eser s.128-129. 
Türkiye'de ikamet eden ve Türk toplumunun bir parçası haline gelmiş bulunan Türk soylunun kişi hallerine giren konularda, ne 2527 sayllı yasa, ne de 2567 sayll DHH yasası özel hüküm getirmemiş olduğundan yabancı sayılacaktır. Bu sonuca katılmak güçtür. İkametgâhını ülkeye getirmiş olan, geçimini Türkiye'de sağlayan, yaşamı için gerekli tüm ilişkilerini ülkede toplamış bulunan kişi hakkında ikametgâh bağlama kuralının uygulanması daha yerindedir. 2567 sayılı DHH yasasının bu yönde değiştirilmesi yerinde olur.

Benzer bir hukukî statï, Türkiye'den kendi istekleri ile Yunanistan'a giden rum ortodoks Türk vatandaşlanna Yunan Devletince uygulanmaktadur. Yunanistan'a yerleşmiş olan rum ortodoks dinine mensup Türk vatandaşına Yunan vatandaşlığı verilmemekte, fakat haklardan Yunanlı gibi yararlanması sağlanmaktadır. Türkiye'deki Yunanlı sayısının azalmasını önlemek amaci güden bu uygulamada da örtülü veya noksan çifte vatandaşlik hali vardır ${ }^{5-6}$.

Örtülü; noksan veya fiilî çifte vatandaşlık konusunda en önemli durum, yetkili makamın onayı ile ûlkede sürekli oturma izni alan yabancının, kendi vatandaşlığı yanında ikame vatandaşlı̆̆a sahip olmasıdır. Oturma izni veya ikamet tezkeresi genel olarak iki ana bölüme ayrılmaktadır. Bunlardan birisi süreli oturma izni diğeri sürekli oturma izni veya süresiz oturma izni (unbefristete Aufenthaltserlaubnis- dauernder Aufenthalt)dir. Sürekli (daimî) oturma izni, medenî hukuktaki sürekli ikametgâh (staendige Wohnsitz) den ayrıdır. Sürekli oturma izni, kuzey Amerika bölgesinde uygulanan yeşil kart (green card) kurumu ile koşuttur. Yurt dışında; örneğin Almanya'da bulunan Türklerin çoğu sürekli oturma iznine sahiptir. 5683 sayılı ve 15.7.1950 tarihli Yabancıların Türkiye'de Ikamet ve Seyahatleri Hakkında yasa süreli ve süresiz ikamet tezkeresi ayırımını getirmemektedir. 5683 md.9'a göre, ikamet tezkeresi süresi en çok

5. Noksan çifte vatandaşlı̆̆a bir baska önek bölünmüş Devletlerin durumudur. Alman Demokratik Cumhuriyeti ile Alman Federal Cumhuriyeti ayrı vatandaşlık yasalarına sahip ikj Devlet idiler. Ancak, Alman Federal Cumhuriyeti, Demokratik Alman itlkesinde oturan Almanları kendi vatandaşı saymakta idi. Konu ile ilgili olarak bkz. Schaetzel, age., s. $108 \mathrm{vd}$.

6. Türk soylu olmayan bölge ülkesi vatandaşlannın siyasî ve ekonomik nedenlerle Türkiye'ye göçlerinj düzenlemek ỉzere Devletin yeni bir yasa hazırladığ anlaşılmaktadır. Yeni metnin de 2527 sayıl yasanun geliştirilmiş bir türü olacağı açıdıdır. Ónemli yenilik çalışma ve ikamet izninin süreli ve süresiz olarak ikiye ayrimasıdır. Ancak, sliresiz ikamet izni için getirilen kstaslar çok sınurlıdır. Ayrıca, İ ve İşci Bulma Kurumunu da yabancılar bürosu haline getirmek hatalıdır. Kaldı ki, yabancılar sistemden yoksun biçimde kategorilere ayrulmaktadır. 
iyi yıldır. 24 Kasım 1977 tarihli Göçmen İşçinin Hukukî Statuisüne İlişkin Avrupa Sözleşmesi md.9'da, Türk hukukunda olduğu gibi oturma iznini süreye bağlamışıır.

Süresiz veya sürekli oturma izni, genel olarak Devletin vatandaşılı yasasının telsik için öngördüğü koşullarına durumu uyan yabancıya verilmektedir. Yabancı, içinde bulunduğu uygun koşullara rağmen, herhangi bir nedenle ülkesinde bulunduğu Devlet tarafından yetkili makam kararı ile vatandaşlığa alınmamakta yani telsik edilmemektedir. Örneğin, Almanya'da sürekli oturan ve süresiz oturma izni bulunan ve Alman vatandaşlık yasasının genel telsik koşullarını yerine getiren Türk vatandaşı, Cermen boylarından birisinin ahalisinden (Volkszugehörigkeit) olmadığından telsik işlemi yapılmamaktadır. Ortaya çıkan ve bireyin aleyhine olan bu durumu kısmen olsun düzeltmek amacı ile süresiz veya sürekli oturma iznine özel bir statui verilmiş ve fiiili çifte vatandaşlık yaratılmıştır.

Geçen yüzyıllarda yabancının ülkede sürekli oturma izni alamayacağ yani ikametgâh edinemeyeceği kuralı geçerli idi. PrensDevlet anlayışından arda kalan anlayışa göre ülkede ikamet, ancak vatandaşa tanınan bir haktır. 20 'nci yüzyılda yabancının, yetkili makam kararı ile ülkede ikamet edebileceği ve bu halde tüm medenî haklardan yararlanacağı kabul olunmuştur. Yetkili makam kararı ile alınan sürekli oturma izni Devletin bireye tanıdığı bir haktır. Kişi lehine bir imtiyaz doğmaktadır. Doğan hak, süreli oturma izninden farkh olarak, geri alınamamaktadır. Hak sahibi ayn vatandas gibi ülkeye giriş ve çıkıs yapabilmektedir. Sürekli oturma izni sahibi, istisnalar saklı kalma koşulu ile suçluların iadesine tâbi olmamaktadır. Devletin yabancı kị̧i lehine bir özverisi (une concession de l'Etat) olan sürekli oturma hakks, ayni zamanda Devletle birey arasında bir siyasî bağ da (le domicile un lien politique) oluş̧urmaktadır. Belirtilen durumdan hareket eden bazı yasa koyucular, ülkede sürekli oturma izni yani fiilî ikametgâhı bulunan yabancının tüm medenî haklardan yararlanacağını ve bunların, kişi hallerine giren konularda, ulusal yasaları yerine ikametgâhı yasalarına tâbi olacaklarını öngörmüş̧ü̈r?

7. Batiffol, Traité Elémentaire De Droit Intemational Privé, Troisième Edition, Paris 1959, No.182'de yetkili makam karan ile illke'de ikamet eden yabancinın medenî haklardan yararlanmasını öngören Code Civil md.13 ile tsviçre'nin ülke'de sürekli oturma izni olan yabancılara ikametgâh yasası bağlama kuralını uygulayan mevzuatı hk. bkz. Simond Les Etrangers domiciliés en Suisse, (Droit International Privé) Lausanne 1926, s.14 ve 35 vd. Ayrica Kegel, Internationales Privatrecht, 3. Auflage, München 1971, s.174. 
Sürekli oturma izni olan veya ikametgâh kurma yetkisi bulunan veyahut yeşil kart sahibi olan birey, biçimsel olarak yani vatandaşlık yasasına göre Alman, Fransız, Amerikalı olmasa dahi, hukukî statü bakımından, istisnalar saklı kalma koşulu ile vatandaşa eşittir. Burada ikame vatandaşlıktan söz edilebilir. Bireyin bir yanda biçimsel veya düzenli vatandaşlığı, diğer yanda yetkili makam kararına dayanarak süirekli olarak oturduğu ve iradesi ile seçtiği Devletin tanıdığı ikame vatandaşlığı vardır. Bu suretle, fiilî veya örtülï veya noksan çifte vatandaşlık ortaya çıkmış olmaktadır. Gerçekte Anayasa md. 62'nin gözönüne aldığ I Türkler, fiilî çifte vatandaşlığı olan Türklerdir. Gerçekte ne 2675 sayılı DHH yasası, ne 5683 saylı yasa ve ne de 403 sayılı T.V.Y. yabancinın illkede ikameti konusunda var olan bu karmaşık durumu gözönüne almışlardir. Ancak, T.V.Y. yabancinın ikameti konusunda var olan bu ayır1mi sezinlemiş, fakat 5683 sayl yabancılarn seyahat ve ikametleri hakkındaki yasayı değiştiremediğinden somut bir sonuca ulaşamamıştır. Olası bir çifte vatandaşlık yasasında yabancının Ülkede ikameti ve Türklerin yabancı ïlkede ikameti konuları ayrıntılı olarak düzenlenmelidir.

\section{Düzensiz Çifte Vatandaşlik}

Düzensiz çifte vatandaşlık halinde kişi; bir yabancı Devletin vatandaşlığını, vatandaşlık hukukunun genel ilkeleri dışındaki bir nedenle ve çoğu kez süreli olarak kazanmaktadır. Vatandaşlık hukuku dışındaki nedenlerle kazanılan ikinci vatandaşlık sürenin sona ermesi ile kaybedilmektedir.

Konuya ilişkin önemli örnek, halen Fransız ordusunun sözleşme ile lejyoner çalıştırmasıdır. Lejyoner çalıştığı sürece aynen Fransiz vatandaşı gibì işlem görür. Fransız ordusuna özgü kimlik belgelerine veya pasaporta sahiptir. Fransız ordusu mensubu olarak işlem görme, lejyoner statüsünün sona ermesi ile ortadan kalkar. Fransa'da lejyoner olan bir Türk görevi sürecince çifte vatandaşlı̆̆a sahip sayılabilir ${ }^{8}$.

Düzensiz çifte vatandaşlık uluslararası hukuk kurallarına dayanarak da doğabilir. Bağımsızlıkları sınırlı olan, yani himaye altında,

8. Ikinci Dünya Savaşından sonra ortaya çıkan Als-ob-Fiktion (vatandaşlık varsayımı) için bkz. Schaetzel, age., s.94. 
sömürge, koloni gibi statülerde olan Devletler ülkesinde bulunan ve doğan yabancıların vatandaşlıklarından diizensiz çifte vatandaşlık hali doğabilmektedir. Ne Hamî Devletin (Fransa), ne de Mahmî Devletin (Tunus) vatandaşı olan fakat üçüncü bir ülkenin (Ingiltere'nin) vatandaşı bulunan bireyin, Himaye altındaki topraklarda doğması ve iki kuşaktan beri o ülkede (Tunus'ta) ikamet etmesi halinde Hamî Devlet (Fransa) vatandaşı sayabilmesi örnektir ${ }^{9}$. Bu sonuç, vatandaşlık hukukunun ilkelerinden ne ius soli ve ne de $i u s$ sanguinis'e uymaktadır. Birey, rızası dışında Fransız vatandaşlığını reşit oluncaya kadar, İngiliz vatandaşlı̆̆ı ile beraber taşıyacaktır. Uluslararası teamüle, Sözleşmelere ve vatandaşlık hukuku'nun genel ilkelerine uymayan bu sonucun kabulü güçtür. Uluslararası statülerin çarpık uygulanmasından doğan ve vatandaşlık hukuku'nun prensipleri ile bağdaşmayan bu hale düzensiz çifte vatandaşlık denilebilir. Ingiliz hukuku, bireyin nzası dışında ve vatandaşlık hukukunun genel ilkelerine aykırı olarak, bir Devletin diğer Devlet vatandaşına, kendi tâbiiyetini vermesi halinde, Devletin egemenlik hakkını suistimal ettiği kabul edilerek, yok vatandaşlık sayılması gerektiğini düşüinmektedir ${ }^{10}$. Vatandaşlık hukuku alanında hakkın suiistimali ve yok vatandaşlık konularının Türk hukukunda da incelenmesinde yarar olduğunda şüphe yoktur ${ }^{11}$.

\section{III. Çifte Vatandaşlı̆̆ın Tarihi Gelişsimi}

İnsanların dünya üzerindeki dağılımı ve Devletler arasındaki paylaştırılması, halen kesin olarak çözümlenememiş bir sorundur. Bireyler, ilk đönemlerde uzun süre soy esasına göre Devletler arasında dağılmışlardır. İlk örgütlenmiş toplumlarda ahali, ırk ve dil birliğine dayanarak oluşmaktadır. Budun (ulus) ırk ve dil birliğine dayalı bir bütündür. lus sanguinis (kan bağı veya kan esası) vatandaş olabilmenin temelidir. Bireyin aynı zamanda, iki ayrı topluluğa dahil olması kurumlaşmı̧ bir husus değildir.

Kan bağı, Şehir Devletlerinde de varlığını sürdürmüştür. Şehir Devletinde de, günümüzde olduğu gibi vatandaşlığın kazanılmasını

9. Örnek hk. bkz. Batiffol, age., No.88; Parry, Plural Nationality And Citizenship With special Reference to the Commonwealth, s.255.

10. Parry, age., s.254, Makarov, age., s.70-72. Uluslararas1 Lahey Adalet Divant aksi görüştedir. Divan, Uluslararası hukukun ilkelerinden aynlmış ve vatandaşlık hukuku açısından Fas ve Tunus toprakJarını Fransız illkesinden saymuştır.

11. T.V.Y. md.7/d ve e bentleri keyfi uygulamaya elverişli hïkïmlerdir. Bakanlar Kurulunun Devletin egemenlik hakkını suiistimal ettiği izlenimini veren kararlar alacağı sanılmamaktadır. 
ve kaybın düzenleyen, genel ve tek düze yasalar yoktur. Bireyin vatandaşlığı somut olaydan hareketle ad hoc karara bağlanmıştır. Yurttaşlık ve hemşehrilik, yine ırk ve kan bağı ilkelerine dayalıdır.

Şehir surları dışında veya bitişik alanlarda oturanların yurttaşlik (citizenship) durumu hakkında da ad hoc karar yöntemi uygulanmıştır. Ancak, sur dışında veya bitişik alanlarda oturanların yurttaş sayllabilmesi için yeni kurumlara gerek olduğu, antik dönemde anlaşılmıştır. Sur dışında veya müicavir alanlarda oturanların yurttaş sayılabilmesi koşullan da ad hoc kararlarla saptanmıștır. Bu yoldan, yetkili makam kararı ile vatandaşlığa alınma yani Telsik kurumu doğmuştur. Antik dönemde telsik'in koşulları, önceden kesin olarak bilinmeyen ilkeler demeti halindedir. Birkaç kuşaktan beri bitişik alanlarda ikamet étmiş ve orada doğmuş olmak, Şehir Devletinin ekonomik yaşamına katkıda bulunmak; tapınaklardan birisinin cemaatine üye olmak, şehir savunmasına katılmak gibi olgulardan hareketle, ad hoc karar verilmiş ve telsik gerçekleştirilmiştir. Vatandaşhk hukukunda görülen bu gelişmeler, henüz çifte vatandaşlığa yol açacak düzeyde değildir. Bireyin, aynı zamanda iki Şehir Devleti'nin yurttaşı olması, sıradan vatandaş için bilinen bir kurum olmamıştır.

Roma Devleti de, başlangıçta antik dönemden gelen rejime uymuştur. Roma'nun fütuhat ile büyümesi sonucunda, Devlet ahalisinin dil, ırk ve külttür çeşitliliği ortaya çkmıştır. Roma Devleti ius sanguinis'i terk etmemiş, fakat ad hoc kararlarla Devletle kişi arasındaki, vatandaşlık bağını saptama yönteminin yürümeyeceğini görmüiştiir. Milâttan sonra 212 yılında İmparator Caracalla tarafından çıkarılmiş olan "Lex Antoniana de Civitate" vatandaşlık yasalarının ilk örneği olmuştur ${ }^{12}$. Ius sanguinis esasını korumuş olan bu yasa da çifte vatandaşlık haline yabancıdır.

Ortaçağ döneminin Devlet düzeni olan feodal rejim vatandaşlık hukuku alanına değişiklik getirmiştir. Devlet ve onun öğeleri olan ülke ve bu ülke üzerinde ikamet eden kişiler, derebeyinin mülküdür. Feodal Devlet, diğer bir deyimle Prens-Devlet sistemi senyör, derebeyi veya prens ile, ïlkenin ahalisinden olan serf; kul, köle veya köylï statüiünde bulunan birey arasında sürekli ve kişisel bir bağ kurmaktadır. Üzerinde oturduğu araziye bağlı olan birey, arazi-

12. Fǔsek, Türk Vatanđaşlık Hukuku, Ankara 1959, s.4. 
nin sahibi prens veya senyörün, siyasî ve hukukî haklardan yoksun tebaasıdır. Bireyin prens veya senyöre sadakat zorunluluğuna "allégeance" denilmektedir ${ }^{13}$.

Allégence'ın temelini süreklilik ve ülkesellik ilkeleri oluşturmaktadır. Süreklilik, bireyin derebeyine, senyöre, prense ve sonraları krala bağlılık ve itaat yemini ettiği varsayımına dayanır. Birey hayatı boyunca bu varsayımla bağlıdır. Bireye evlilik veya nesep bağı ile bağlı olanlar da aynı varsayıma uymak zorundadır. Bunun sonucunda, birey bir yandan hayatı boyunca vatandaşlık değiştirememekte, diğer yandan ailede tâbiiyet birliği aranmaktadır.

Ülkesellik kişiyi toprağa bağlamaktadır. Bireyin toprağa bağlanışı da iki yönliudür. Önce, vatandaşlığın doğum ile kazanılmasında ius soli ilkesi esastır. Birey ülkesinde doğduğu prensin, senyörün vatandaşıdır. Ülkeselliğin ius soli yanında yer alan ikinci öğesi, ülkede ikamet zorunluluğudur. Bireyin ülkede ikamet etmemesi cezaî sorumluluğa yol açar. Birey toprakları üzerinde doğduğu PrensDevletin vatandaşı olacak ve doğduğu topraklar uizerinde ikamet edecektir. Ülke'de ikamet zorunluluğu bireyin yaşamının temelidir.

Prens-Devlet döneminde ülkede siyasî denetimi sağlamak ve kişinin tâbiiyet bağını açıkca ortaya koyabilmek için gerekli görülen ikamet kurumu üç ayrı biçimde olmakta idi. Bunlar sürekli bulunma (subtidus perpetuus), geçici bulunma (subtidus temporalis) ve taşınmaz mülkiyeti nedeniyle bulunma olarak sıralanmaktadır. Bu sıralama, günümüzde de yabancının illke'de ikameti açısından özellikle avrupa ülkelerinde geçerlidir. Prens-Devlet ile serf arasındaki vatandaşlık bağının temeli sürekli ülkede bulunmadır. Yabancı sanatkârlar, diplomatlar, tacir ve seyyahlar ülkede geçici olarak bulunurlar. Zenaatkârların da ülkede geçici olarak bulunmaları, özel izin almaları halinde olasıdır. Bu düzende, serseriler dışında vatansız bulunmaz. Çifte vatandaşlığın fiilen bulunması önlenmek istenmiştir. Herkes ülkesinde sürekli olarak bulunduğu Prens-Devlet'in tebaasıdır. Bireyin iki ayrı ikametgâhı veya sürekli olarak bulunduğu iki ayrı Devlet ülkesi bulunmamalıdır. Bir kimsenin iki ayrı ülkede sürekli olarak oturması, amelî yönü olmayan teorik bir haldir. Bu teorik ve istisnai hal için önerilen çözüm yolu ise, kişinin ülkesinde fiilen bulunduğu Devlet vatandaşı sayılmasıdır.

13. Allégeance kavramı hk geniş bilgi için bkz. Berki, Devletler Hususî Hukuku, Cilt I, 6'neı Baskı, 1966 Ankara, s.36 vd. Allégence'ı krahın şahıına bağlılık olarak gören anlayış için bkz. Fişek, age., s.4. 
Prens-Devlet dizgesinde kişinin vatandaşlığını değiştirmesi prens ve senyörün iznine bağlıdır. Vatandaşlığın sürekliliği ilkesine aykırı davranış cezaî sorumluluğu getirir. İkametgâhı yabancı ülkeye götürme tâbiiyetin kaybına yol açar. Tâbiiyetin kaybının eş ve reşit olmayan çocuklara etkisi ise çoğu kez verilen izinde gösterilmektedir. İnin verilmesinde yeni bir ikametgâh seçimi en önemli koşuldur. İzin ile ikametgâh değiştirmenin, vatandaşlık hukuku açısından en önemli sonucu Telsik kurumunun ortaya çıkmasıdır. Telsik ile vatandaşlığın sürekliliği ilkesi yumuşatılmış ve bireyin ç1karlan kollanmak istenmiştir. Telsik uygulaması çifte vatandaşlığa yol açmayacak biçimde olmalıdır. Bireyin iki prense veya senyöre kulluk etmesi, getirdiği çok ağır yükümlülükler nedeniyle olanaksızdır. Kısaca, feodal düzende iki ayrı ikametgâh olamaz ve kişinin çifte vatandaşlığı bulunamaz. Feodal düzende ikametgâh kayıtları şahsî hal kayıtlarının önünde yer alır. İkametgâh kayıtları öneminden dolayı, Prens-Devlet'in kolluk kuvvetleri tarafından tutulur, fakat şahsî hal kayıtları ise kilise tarafından düzenlenir. Doğum, vaftiz, nikâh ve ölüm kayıtlarını her kilise kendi cemaatı için tutmuştur. Feodal dönemden gelen bu kayit ve sicil düzeni günümüzde de varlığını sürdürmekte ve Yabancılar Hukukunun ikametgâh anlayışının temelini oluşturmaktadır. Vatandaşlık çatışmalarının çözümünde önemli yeri olan ikametgâh veya mûtaden bulunulan yer kavramlarının doğru uygulanabilmesi için tarihi gelişimi iyi bilmek gereklidir.

Çifte vatandaşlık, İngiliz İmparatorluğu'nun çok uluslu yapısı nedeniyle, Common law'da sürekli tartışma konusu olmuştur. Common law, vatandaşlik hukuku alanında, feodal dönemdeki düzenlemenin etkisi altında kalmış, krala bağlılık ve sadakatı ifade eden allegiance kurumunu esas almıştır. İmparatorluğun çok uluslu olması ve buna bağlı ülkelerin değişik statüleri bulunması, allegiance'dan hareket eden Common law'u yeni bir dizge oluşturmağa zorlamıştır. Dominyonlar, sömürgeler, himaye altındaki Devletler, vesayet ve manda altındaki Devletler, İmparatorluğa bağlı Devletlere ilişkin değişik statü örnekleridir. Vatandaşlık hukuku düzenlemesi, bağımlı Devletin içinde bulunduğu hukukî statüye göre değişmektedir. Örneğin, sömürge Devletin bir parçası sayıldığından, anavatandaki yasalar sömürge'de de geçerli olmalıdır. Bu sonuç, sömürge ahalisine otomatik olarak İngiliz vatandaşlığını vermemektedir. Sömürge ahalisinin vatandaşlığı, sömürge türüne göre değişmektedir. İskân sömürgesi olan Avusturalya'ya yerleşen cermen kökenli ahalinin İngiliz vatadaşlığını kazanması ve koruması koşullan çok basittir. 
Bu durum çifte vatandaşlığın ortaya çıkmasını kolaylaştıran bir tutumdur. Aynı Avusturalya'da bulunan yerli ahalinin ise İngiliz vatandaşlığını kazanması ve koruması çok zordur. Aynı biçimde, geçmişte istismar sömürgesi olarak görülen Hindistan, Pakistan ahalisinin İngiliz vatandaşlığını kazanması güç koşullara bağlanmiştır. Avusturya'nın yerlileri ile Hindistan ve Pakistan ahalisi açısından çifte vatandaşlık önlenmek istenmiştir. Vatandaşlığı kazanmaya ve korumaya ilişkin tüm bu statü farklarını saptarken Common law önce bir hayli deneyim kazanmış, sonra çözüm bulmakta zorlanmıştır.

Bir başka örnek, himaye altındaki Devletler halinde görülür. Himaye altındaki Devlet, himaye eden Devletin ülkesine dahil değildir. Hamî Devlet ve Mahmî Devlet kendi vatandaşlık yasalarına sahiptir. Bu farklı vatandaşlık yasalarının uygulamadaki yeri Himaye Andlaşması hükümlerine göre saptanır. Himaye Andlaşmaları hükümleri ise halden hale farklıdır. Öğreti İngiliz Uluslar Topluluğuna üye her Devleti ayrı ayrı ele almakta ve çifte vatandaşlığın orataya çıkması olanaklarını, ilgili Devletin içinde bulunduğu statüye ve andlaşmalara göre tek tek incelemektedir ${ }^{14}$.

Common law'un yanında yer alan Statutes law (yasalar hukuku-mevzuu hukuk-yazılı hukuk) da karmaşık konuyu bir tek yasa ile duizenleyememiştir. 1730, 1772, 1948 tarihli The British Nationality Act, çifte vatandaşlığ turalization Act, 1934 tarihli British Protected Persons Order konuya ilişkin mevzuattan örneklerdir. Bu yasal düzenlemelere rağmen, halen Common law, Íngiliz vatandaşlik hukukunu düzenleyen temel kurumdur. Değişik gereksinmeleri karşılamak üzere, tarihi gelişim içerisinde terim çokluğu ortaya çıkmıştur. Subject (tebaa), allegiance (uyrukluk), citizenship (yurttaşlik), Nationality (vatandaşlık) en sık kullanılan terimlerdir ${ }^{15}$.

Kullanılan terimler arasında Subject terimine, Common law tarafindan bir üst kavram niteliği verilmiştir. Bu üst kavram İngiliz hukukuna özgü değişik kısımlara ayrılmaktadır. Önce Citizen British Subject (Îngiliz tebaası yurttaş), sonra Non-Citizen British Sub-

14. Belirtilen biçimde bir inceleme için konu üzerine önemle eğilmiş olan Parry, age. s.285-291.

15. Terminoloji konusunda bkz. Uluocak, Türk Vatandaşlık Hukuku, İstanbul 1968, s.18 vd. 
ject (İngiliz tebaası yurttaş), sonra Non-Citizen British Subject (Yurttaş olmayan İngiliz tebaası) ayrica Natural-Born Subject (dogumdan tebaa), bir dördüncü hal Naturalized-Subject (telsik edilen tebaa- Yetkili makam karan ile vatandaşlığa alınan tebaa), beşinci hal British Protected Persons (İngiliz korumasındaki kişiler) ve sonuncu olarak Aliens (yabancılar) sayılabilecek kategorilerden örneklerdir. Kategoriler kendi içlerinde alt ayırımlara tâbidirler. Her kategorinin kendisine özgü vatandaş sayılma kurallanı ve buna bağ1 olarak hukukî statüsü vardır.

Karmaşık olan İngiliz vatandaşlı̆̆ kavramının anlamını açıklayabilmek için konuyu 1948 'den öncesi ve sonrası diye ayırarak incelemek gereklidir. 1948'den önce, İngiliz vatandaşı (British nationals), istisnalar saklı kalma koşulu ile anavatanda doğan ve İngiliz ana ve babadan olan kisilerdir. İngiliz vatandaşı, Britanya tebaasının (British subject'in) içinde yer alan bir kategoridir. Her İngiliz tebaası, belirtilen anlamda İngiliz vatandaşı değildir. Örneğin, İngiltere'nin korumasındaki kişi (British protected persons), Kraliyet pasaportunu taşır ve tebaa sayılır. Kraliyet tebaası sayılmak için ius soli veya ius sanguinis"in doğrudan uygulanması gerekmez. Birey, İngiliz milletler topluluğuna dahil cemaatlerden birisinin yurttaşi (hemşehrisi) olduğunu yargıç önünde kanıtlamak durumundadır. Sözü edilen tâbiiyet yalnız uluslararası hukuka yöneliktir. İngiliz pasaportu taşıyan ve koruma altında olan kişi iç hukuk açısından (domestically aliens) sayılmaktadır. Üçüncü bir Devlet, koruma altındaki kişiyi İngiliz vatandaşı saymayabilir veya çifte vatandaşlığın varlığını kabul edebilir. Bu sonuç İngiliz hukukunu etkile$\mathrm{mez}^{16}$. Bir İngiliz tebaasının hem dominyon cemaatı pasaportu ve hem de İngiliz pasaportu taşıması mümkündür. İngiliz Devleti Common law'un dışında bir düzenlemeye ulaşmak amacı ile 1948 vatandaşlık yasasını çıkarmıştır.

1948 İngiliz vatandaşlık yasası (The British nationality act) bağımsızlığa kavuşan İngiliz sömürge ve koloni ahalisinden bir kısmını, özellikle uzun süre İngiliz çıkarları için çalışmış olanlarını korumak amacını gütmüştür. Bu amaca ulaşabilmek için İngiliz vatandaşlığı kavramını yasa, Common law'dan daha geniş bir esasa

16. Sömürgeci bir Devlet olan Fransa'da da Common law'dakine benzer bir gelişme vardır. Citoyens français, sujets français ve resortissants kavramlan açısından bkz. $\mathrm{Ba}$ tiffol, age., No.67. Ressortissant, bir Devletin egemenliğine tâbi olan yabancıyı da ifade etmektedir. 
oturtmuştur. Önce, İngiliz korumasında olan kişilere, önemli oranda İngiliz vatandaşlığı statüsü verilmiştir. Sonra, koloni, sömürge, vesayet ve manda altındaki ülke ahalisinden bazılarına, sinırlı oranda da olsa İngiliz vatandaşı sayılma olanağı tanınmıştır. Yasa kapsamına girdiğine inanan kişi, bu savını yargıç önünde kanıtlamak zorundadır. Anlatılmağa çalışılan bu karmaşık sistem, vatandaşlık hukuku alaninda hukukî statii veya hukukî durum nazariyesi olarak isimlendirilmektedir.

Common law A.B.D. (Amerika Birleşik Devletleri) bağımsızlık savaşına kadar çifte vatandaşlığın varlığını kabul etmemiștir. 4 Temmuz 1776 tarihinde bağımsızlı̆ğını kazanmıs olan A.B.D. ius soli ilkesine dayanarak, ülkede bulunan binlerce İngilizi Amerikan vatandaşı yapmıştır. Common law orta çağdan beri geçerli olan vatandaşlığın sürekliliği (principle of indissoluble allegiance) ilkesine dayanarak kişileri İngiliz vatandaşı saymış̧ır. Bu gelişme ile çifte vatandaşlık, Common law'un önemli konuları arasına girmiş̦tir. Her sömürge veya bağımlı Devlet, bağımsızlı̆̆ını kazandıkça çifte vatandaşlık konusu yeniden canlanmış ve sonuçta Common law çifte vatandaşlığı, vatandaşlık hukukunun bir kurumu olarak kabul zorunda kalmıştır.

Common law ortaya çıkan vatandaşlık çatışmaları konusunu, yine kendine özgü hukukî anlayışıla çözümlemiștir. Çifte vatandaşlı̆ı olan birey, vatandaşlıklarından biri İngiliz olsa dahi, ikametgâhı veya mûtaden bulunduğu yer Devleti vatandaşı sayılacaktır. A.B.D. ikamet eden bir İngilizi, İngiliz yargıcı Amerikalı sayabilecektir. Ingiliz Vatandaşlik Dairesi (The Nationality Commissioners), 1869 yılında çifte vatandaşlık konusunu inceleyen raporunda, doğduğu yabancı ülkede ikamet eden ve o yabancı ülke vatandaşı olan bir İngilizin üzerinde, Ingiliz hükûmetinin Kraliyet vatandaşl1ğı hakkını iddia edemeyeceği sonucuna varmıştır ${ }^{17}$.

Kara Avrupasının çok uluslu olmayan ve Alman birliğini tamamlayamamış olan Devleti Prusya "hukukî statü" dizgesini kabul etmemiştir. Prusya'nın anlaşıyına göre, vatandaş sayılma koşulları ad hoc dizgeye değil, açık yasa hükümlerine dayanmalıdır. Vatandaş sayılma koşullarını egemen Devlet, hür iradesine dayanarak çıkaracağı özel yasada hükme bağlamalıdır. Sonra, yasaya göre va-

17. Bkz. Parry, age., s.258. 
tandaş sayılan bireyler eşit statüye sahiptir. Vatandaşlar, kategorilere ayrılarak, farklı hukukî statülere tâbi tutulamazlar. Buna yasal rejimin tekliği ilkesi denilmektedir. Üçüncü olarak, vatandaşlık rrkla ilgili değildir. Tüm Almanların Alman vatandaşı olması istenemez. Dördüncü olarak, vatandaşlık hukuku'nun temel ilkesi ius sanguinis'dir. Íus soli veya ikametgâh istisnadır. Beşinci olarak, vatandaşlık ile askerlik hizmeti arasında ilişki vardır. 1842 tarihli Prusya Vatandaşlık Yasası düzenlemesi Devletsel Nazariye veya Yasal Rejim olarak isimlendirilmiştir.

Devletsel dizge, ilke olarak çifte vatandaşığga karşıdır. Elden geldiğince, vatandaşlığın tekliği ilkesi korunmalıdır. Bu dizgeyi savunan Prusya'nın sorunu ülke dişında kalan Alman asıllılar bulunmasıdır. İstisnaen de olsa uluslararası hukuka göre yurt dışında oturan Almanlar çifte vatandaşlığa sahip olabilirler. Devletin kendisine kültür, ırk ve dinî nedenlerle bağlı olmayan kişilere vatandaşlık vererek, çifte vatandaşlığa, hiç gerek olmadan yol açmaktan kaçınmas1 gerekir. Almanya, Fransa, Hollanda gibi ülkelerde ikamet eden Türklerin, sayılan ülke vatandaşları ile din, dil ve ırk birliği içinde bulunmadıklarından çifte vatandaşlığa sahip olmamaları gerekir. Bu sonuç gerçeklère uygun değildir. Külttürel, rrkî ve dinî nedenlere bakılmadan kişilere vatandaşlık verilmekte olduğu günümüz gerçegidir $^{18}$.

Devletsel dizge ile Common law'da geçerli hukukî statü dizgesinin etkileri vatandaşlik hukukunu aşar düzeydedir. Her iki sistem yasaların çatışmasını da etkilemişlerdir. Common law yasaların çatışması alaninda ülkesellik ilkesini yeğlemiştir. Ancak, ülkesellik ilkesi kişi hallerine ilişkin konularda kurılmalıdır. Özellikle, kişi hallerine iliş̧in konularda yasaların ülke dışında uygulanması adaletin gereğidir. Bir Devletin yasalanı yabancı ülkede kazanılmiş haklar kuramına göre hüküim ifade eder. Birey, ikamet ettiği veya mûtaden bulunduğu Devlet ülkesi yasalarına dayanarak haklar kazanır. Bireyin, ikametgâhı veya mutaden bulunduğu yer Devleti yasalarına göre kazandığı haklar, ikametgâhın veya mûtadan bulunulan yerin değiştirilmesj ile yani başka bir ülkeye taşınması ile sona ermemektedir. Kişi bir ülkede kazandığı hakları beraberinde başka

18. Dinî ve ırkî nedenlerle toplu vatandaşlıktan çıarma veya vảtandaşıı verme olaylanın örnekieri vardır. Hitler Almanyası'nda yahudiler, dinî ve ırkî nedenlerle topluca Alman vatandaşı̆ı̆ın kaybetmişlerdir. Aynı yahudiler gittikleri yabancı ülkelerde Alman vatandaşı sayılmağa devam olunmuşlardır. Israil'in dünyadaki yahudileri dinî ve ırkî nedenlerle vatandaş saymasi da ayri bir konudur. 
ülkelere de götürebilmektedir. Bu kuram bireylerin çıkarlarına önem vermekte ve Devletin çıarlarını ikinci plânda tutmak çabasindadur.

Devletsel nazariye, egemenlik haklarına dayanarak Devletin kendi çıkarlarına en uygun gelen hükümleri getirme hakkından hareket etmektedir. Devletin egemenlik hakkına dayanarak koyduğu yasalar ülkeseldir. Devlet, bireyin hukukî statüsünde istirar, mübadele hayatında güven, uluslararası işbirliği ve teamül gereği, istisnaen yabancı yasaların kendi mahkemeleri tarafindan uygulanmasinı kabul edebilir. Hangi konularda ve ne oranda yabancı yasaların ulusal mahkemeler tarafindan uygulanacağını, her Devlet kendisi saptar. Örneğin, 2675 sayılı DHH yasası, Türk Ticaret Yasası'nın 678-687'nci maddeleri hangi hallerde yabancı Devlet yasası'nın Türkiye'de uygulanabileceğini gösteren hükümlerdir. Bu nazariyeye göre Devletin çıkarları, kişinin çıkarlarından önde gelir.

İslâm hukukunun geçerli olduğu Osmanlı Devletini, yukanda yer alan iki kuramdan birisine sokmak olanaksızdır. Devletin temel öğesi olan egemenlik hakkı bir yandan dinî ilkelerle, diğer yandan kapitülasyonlarla sınırlıdır. İslâmi inanışta erek (hedef) Kurân-ı Kerim'in emirlerine uygun bir düzen yaratmaktur. Bu düzende insanların Devletler arasında dă̆ııımı hükme bağlanmamıştır. Vatandaşlık zonunlu bir kavram değildir. İslâm anlayışına göre, tïm müslümanlar tek bir yönetime sahip olmalıdır. Bulundukları ülke neresi olursa olsun müslümanlar Kurân-ın emirlerine göre yönetilmelidir. Bu birlik fikri, mezheplerin Kurân'in hükümlerini ayn yorumlamaları ve büyük mezheplerin kendi gereksinmelerine uygun bağımsız Devletler kurmaları sonucunda bozulmuştur. Ülke'de ki insanların yerli müslüman ve yabancı müslüman diye bölünmesi kaçınılmaz bir gerçek olmuştur. Sonuçta, müslüman Devletler de vatandaşlık kavramını hukuk sistemlerine dahil etmişlerdir.

Müslüman Devletin ülkesinde bulunan müslüman ahali arasında mezhep ve ırk birliği olmayışı sorun olarak ortaya çıkmışır. Örneğin, Osmanlı toprakiarından olan Hicaz'da oturan bir Vahabî Arap ile İstanbul'da oturan bir Bektaşi dedesi veyahut Mısır Vilâyetinde oturan bir Fatimî ile Selanik'te oturan bir Hanefî tebaa arasında şahsi statï açısından fark olmuştur. Örneğin, Osmanlı Devletinde vergi ve toprak hukuku konularında her eyâlete veya vilayete özgü, fetihten önce geçerli olan kurallar, bazı ufak değişikliklerle 
aynen korunmuştur. Buna, yasaların yerelliği ilkesi denilmiştir. Kişi halleri ve özellikle aile hukuku alanında her mezhebin kendi örf ve âdeti ile içtihadına geçerlik tanınmıştır. Buna yasalann şahsiliği ilkesi denilmiştir ${ }^{19}$. Kısaca, Osmanlı Devletinde müslüman ahali bağlı olduğu mezhep ve oturduğu bölgeye göre, hukukî statü bakımindan kategorilere aynlmıştır. Sultan Sưleyman'ın Kanunnamesi dahi şahsi hal, aile hukuku, miras hukuku alanlarında bölgeselliği önleyip, yasa birliğine yol açmamıştır.

Gayr-1 müslüm ahali de, içinde bulunduğu hukukî statï bakımindan birlik göstermemektedir. Osmanlı ilikesinde ikamet eden veya oturan gayr-1 müslim tebaaya, kendilerine özgü bir statü uygulanır. Örneğin, Sofya'daki bir Bulgar miras hukukuna ilişkin dâvalarında, kadın erkek eşitliğine uyan kilise mahkemesine gidebileceği gibi, kadının miras hakkını kısıtlayan şer'i mahkemeye de gidebilir. Gayr-1 Müslimler de kendi aralarında kategorilere ayrılmış bulunmaktadır.

Osmanlı Devletinde vatandaşlık bağının kuruluş ilkelerini gösteren sistematik bir yasalaştırma 1869 yılında gerçekleştirilmiştir. 1869 yllından önce vatandaşlık bağının kuruluş ölçittleri idarenin takdir yetkisine geniş̧ yer veren, çoğu kez belirsiz kavramlardan oluşmuştur. $1869^{\prime}$ dan önce, Osmanlı vatandaşlik hukuku'nun en tutarlı kuralı, gayr-ı müslimlere uygulanan dinî telsiktir. Müslümanlığı kabul eden hıristiyan, aslî vatandaşlığını korusa dahi Osmanlı tebaası olmaktadir.

Common law, Osmanlı Devletinden farklı olarak bir yandan çifte vatandaşlığı önleme çabasına girişmiş, diğer yandan ortaya çıkabilecek çifte vatandaşlik hallerinde bireyin hakkını kötüye kullanması olasılığı ile mücadele etmiştir. Osmanlı Devleti kabul ettiği dinî telsik ile, en azından çifte vatandaşlık olasılığını kabullenmiştir. Osmanlı Devleti kapitülasyon sahibi Devletlerin gayr-1 müslimlere uyguladıkları telsik ve onun sonucunda oluşan çifte vatandaşl1ğın suistimallerine engel olamamıştır. Kapitïlasyon sahibi Devlet, gayr-1 müslim Osmanlı tebaasına, bazen para karşılığı kendi vatandaşlı̆̆ını vermiş ve bireyi çifte vatandaşlık hakkına sahip kılmıştır $^{20}$. Para karşılığında verilen vatandaşlik, bazılarına göre yok işlem, diğerlerine göre, Devletin egemenlik hakkının suistimalidir ${ }^{21}$.

19. Islâm Ansiklopedisi, Istanbul 1947, 36. Cüz, s.617.

20. Kapitălasyon rejiminde vatandaşlık için bkz. Sevił̧-Sevił̆, Devletler Hususî Hukuku, Úçincï Bast, Istanbul 1962, s.61 vd.

21. Makarov, age., s.70-72 vd. vatandaşlık hukukunda yok işlem, hakkın suijstimali konulannda aynntuls bir inceleme mevcuttur. 
Devletin vatandaşlık hukuku alanındaki egemenlik hakkı sınırlıdır. Andlaşmalara uymayan, uluslararası teamüle aykın olan ve vatandaşlık hukuku'nun temel ilkeleriyle bağdaşmayan vatandaşlık bağı, ister yok işlem, ister Devletin egemenlik hakkını suistimali olarak kabul edilsin hükümsüzdür. Özellikle Rusya'nın gayr-1 müslim Osmanlı tebaasına verdiği ikinci vatandaşlık, ne vatandaşlık hukukunun genel ilkelerine ve ne de uluslararası teamüle uygundur. Yok işlem savını İngiltere dinletebilmiş, fakat Osmanlı Devleti kabul ettirememiştir.

Osmanlı Devleti çareyi statü değişikliğinde bulmuştur. 1869 tarihli Tabiiyet-i Osmaniyeye Dair Nizamname (veyahut Tâbiiyet-i Osmaniye Kanunnamesi) ile, hukukî statü dizgisinden ayrılınmış ve kara avrupasından geçerli olan Devletsel ve Yasal rejim nazariyesine geçilmiştir. 1869 tarihli yasaya Zeyl md.9 hükmünden anlaşıldığına göre, çifte vatandaşlık sistem değişikliğine rağmen Osmanlı hukuk düzeninin bir sorunu olmağa devam etmiştir.

Tarihi inceleme surasında Ingiltere ve Almanya üzerinde durulması, Türklerin bu iki Devletin vatandaşlık hukuku uygulamalarından yararlanacakları noktaların bulunmasıdır. Önce belirtmek gerekir ki, Türkiye'nin coğrafi konumu çifte vatandaşlı̆̆a çok elverişlidir. Gerek balkanlar, gerek Ortadoğu, tüm tarih boyunca birçok ufak ulusa ve birçok dine barınak olmuşlardır. Sonra Türkiye'nin hızlı nüfus artışı sorunu ve bu soruna bağlı olarak işsizlik problemi vardır. Türkiye insan gücui ihraç zorundadır. Ingiltere'ye bağımlı ülkelerin bağımsızliklanını kazanmaları halinde dahi, eskiden sömürge veya koloni olan ülke ahalisinden İngiliz kültürüne bağlı olanları, dinleri ve urklarına bakılmaksızın kaybetmek istememiştir. Ülkeyi kaybetmiş, fakat İngiliz kültürüne bağlı insanlarla ilgisini tebaa kavramı aracılığı ile, çifte vatandaşlık haline önem vermeden sürdürmüştür. İngiltere vatandaşlık hukukuna, fiilen var olmayan bir anlam vermeğe çalışmıştır.

Almanya ise kaybettiği topraklar üzerinde oturan Alman insanını ve Alman varlığını korumak için vatandaşlık hukukundan yararlanmak istemiştir. Almanya kaybettiği savaşlarda insan kaybını en az düzeyde tutabilmek için, ve ekonominin insan guicü açığını kapatabilmek için, ülke dışında oturan Almanların hukukî statüilerini vatandaşınkine yaklaştırma çabasına girişmiştir. Almanya bir 
yandan da, İngiltere'den farklı olarak kaybettiği topraklarda oturan Almanların anavatana göçünüi önlemeğe çalışmış ve o topraklarda Alman varlığını korumak istemiştir. Örneğin, Birinci Dünya Savaşından sonra Alman soylu Polonya vatandaşı pasaportu taşıyanların sayısı hiç de küçümsenemezdi. Bu uygulama sonucunda ortaya, sürekli örtülü, noksan veya fiilî çifte vatandaşlık hali çıkmıştır. Türkiye'nin hazırlayacağı bir çifte vatandaşlık yasası ile vatandaş̧ık hukukunda uygulayacağı sistemi saptaması gereklidir ${ }^{22}$.

\section{Düzenli Çifte Vatandassliğı Ortaya Çıkaran Olgular}

Vatandaşlık yasalarının, vatandaşlığın kazanılmasına ilişkin kurumları aslî tâbiiyet ve içinde telsik'in de yer aldığı müktesep tâbiiyettir. Aslî tâbiiyet yoluyla çifte vatandaşlık bazı Devletlerin kan esasını diğerlerinin toprak esasını kabul etmeleri sonucudur. Günümüzde nesep bağı ile çifte vatandaşlı̆̆ın doğması, Devletler arasındaki ilke farklılığını aşar bir durum göstermektedir. Aynı ilkeyi, örneğin ius sanguinis'i benimsemiş iki ayn ülke vatandaşı eşlerin evlilik içinde doğan çocukları çifte vatandaşlığa sahip olabilmektedir. Örneğin, Alman baba ve Türk anneden evlilik içinde doğan çocuk hem babanın, hem de ananın vatandaşlığını alabilmektedir (T.V.Y. md.1).

Feodal düzende, evlilik içinde doğan çocuk babasının vatandaşhığını almıştır. Bu uygulama, kadın erkek eşitliği ilkesi ve Devletlerin genç nüfusa olan gereksinimleri karşısında önemini yitirmiştir. Sahih nesepli çocuk hem annesinin ve hem de babasının vatandaşlığını alabilmekte ve bu yoldan çifte vatandaşlık doğmaktadır. (T.V.Y. md.1). Gayr-1 sahih nesepli çocuk, herkesin bir vatandaşlığı olması gereklidir ilkesinden hareket ile annesinin vatandaşlığını almaktadır. Sonrada, baba ile nesep bağı kurulması ve çocuğun babasının vatandaşı̆ı̆ını da alması halinde yine çifte vatandaşlık hali bulunmaktadır. Evlâtlığın vatandaşlığını kaybetmemesi ve fakat evlât edinenin vatandaşlığını kazanması halinde de çifte vatandaşlık ortaya çıkmaktadır (T.V.Y. md.3). Ayrıca, evlât edinen karı kocanın ayrı Devletler vatandaşı olmaları ve her iki Devletin de evlâtlığa vatandaşlıklarını vermeleri halinde çifte vatandaşlık veya çok vatandaşlık hali ile karşılaşılmaktadır.

22. Telsik yoluyla Alman vatandaşı olan bir Türk Alman halkuna mensup (Deutsche Volkszugehörige) vatandaş deŏ̉ildir. Volkdeutsche hk bkz. Schaetzel, age., s.94 vd. $248 \mathrm{vd}$. 
Çifte vatandaşlığa yol açan en eski hukukî ilişkinin evlenme olduğu bir gerçektir. Feodal düzen elden geldiğince çifte vatandaşlığa engel olma çabasını göstermiştir. Prens-Devlet tâbiiyet birliği ilkesini getirmiştir. Tâbiiyet birliği kocanın vatandaş̧ı̆̆ı lehine gerçekleşmektedir. Karı, kocanın vatandaşlığını kazanır ve kendi vatandaşlığını kaybeder. Koca lehine tâbiiyet birliği iki yönden sakıncalı görüilmüştür. Önce, tâbiìet birliği kuralı, kadın erkek eşitliği ilkesine aykırıdır. Sonra, kadının vatandaşı olduğu Devlet, doğacak çocuklar da düşülünürse, kocanın mensup olduğu Devlet lehine önemli nüfus kaybına uğramaktadır. Bu çekişme, uygulamada kadının an'asıl vatandaşlığını korumasına ve bununla birlikte, çoğu kez kocanın vatandaşlığını da almasına yol açmaktadır. Günümüzde, yabancı ile evlenen kadının çifte vatandaşlığının bulunması büyük olasiliktır $^{23}$.

Prens-Devlet telsik yoluyla çifte vatandaş olunmasını da engellemeye özen göstermiştir. Kişi, ancak prens veya senyörden izin alarak ikametgâhını ve dolayısıyla vatandaşlığını, telsik yoluyla değiştirebilmektedir. İkametgâh değişikliği izninin ülkesine gidilen prens veya senyöre gösterilmesi gereklidir. Bu yoldan, önce iki ikametgâha, șonra çifte vatandaşlığa egel olunmuştur. Íkametgâh kayıtları, kilisenin tuttuğu nüfus sicilinden daha büyük önem taşıdıklarından, Devletin kolluk kuvvetleri tarafından tutulmuştur.

Feodal düzendeki kilise ve Prens-Devlet çekişmesi Türk hukukunu yaşamadığı tarihi bir olgudur. Telsik'in sıkı denetimi A.B.D. bağımsızlık savaşı ile önemli bir darbe yemiştir. Birey, tebaası olduğu Devletin çıkma iznini getirmeden, ilk başlarda telsik olunmuştur.

A.B.D. telsik için kural olan ikametgâh değişikliği izni veya çıkma belgesi aramadan, ülkede doğmuş olan Íngiliz vatandaşlarını ius soli, ülkede ikamet eden İngiliz vatandaşlannı da özel telsik yoluyla Birleşik Devletler vatandaşı yapmıştır. Birleşik Krallık ise vatandaşlık bağının sürekliliği ilkesini ileri sürerek, A.B.D. vatandaşlığı kazananların halen Îngiliz vatandaşlıklarının sürdürdüğünü kabul etmiştir. Bu gelişme artık çifte vatandaşlı̆̆n önüne geçilemeyeceğini göstermiştir.

23. Bu olasılığ gợüislemek amacı ile 1963 tarihli Cok Vatandaşhı Hallerinin Azaltılmasına ve Çok Vatandaşlık Halinde Așkerlik Yükümüne Dair Avrupa Konvansiyonu (Strasbourg Konvansiyonu) önerilmiştir. 
T.V.Y. md. 5-8 ve md. 15-18 hükümleri, Türk hukukunda da telsik yoluyla çifte vatandaşlı̆̆ın kolayca doğabileceğini göstermektedir. Telsik isteminde bulunan bireyin, vatans1z olması hali saklı koşulu ile, vatandaşı olduğu Devletten "Çıkma Belgesi" getirmesi istenmemektedir. Ç.kma belgesi koşulu aranmadan yapılan telsik, bireyi çifte vatandaşlığa özendirici niteliktedir. Aynca, Telsik'in ana koşulu olan ülke'de ikamet aranmadan yapılan telsik, çifte vatandaşlığı daha da kolaylaştırıcıdır. T.V.Y. md.7'nin Türkiye'de doğmuş olan ve ikamet etmekte bulunan yabancılara fevkalade telsik yoluyla Türk vatandaşlığını kazanma olanağı getirmemiş olması da ayn bir isabetsizliktir. T.V.Y. çifte vatandaşlık alanındaki tutarsız düzenlemeleri, Türk vatandaşlık hukukunun Common law'daki gibi bir tarihi gelişim göstermemiş olduğunun kanıtıdır. Bu eleştirilerle, vatandaşlık yasası gibi ülkenin insan varlığı ile ilgili bir yasayı dengeli biçimde yapmanın güçlüğü vurgulanmaktadır.

Konu ile doğrudan ilgisi bulunmayan, fakat genel olarak tâbiiyet hukukunun bir parçası olan şirketlerin ve gemilerin çifte tâbiiyeti konusuna da işaret edilecektir. Uluslararası şirketlerin birden çok ülkede idare veya muamele merkezlerinin bulunması halinde çifte tâbiiyetten söz edilebilir. Kural olarak gemilerin de çifte tâbiiyetinden söz edilememektedir. Bu genel ilke günümuizde değişme eğilimi göstermektedir. Donatanların, ucuz emek ve geniş vergi ayricalıklarından yararlanmak amacı ile gemilerini Liberya veya $\mathrm{Pa}-$ nama gibi Devletlerin sicillerine kayıd ettirdikleri ve bunların bayraklarını çektikleri günümüz gerçeğidir. Almanya gibi bazı Devletler bu gerçeği kabullenmişler ve donatanlarının gemilerini iki ayn Devlet gemi siciline kayıd ettirmelerine izin vermişlerdir. İki ayrı gemi siciline kayıtlı geminin, doğal olarak iki ayn gemi tasdiknamesi ve dolayısıyla iki ayn bayrak çekmeğe hakkı olabilir. Bu uygulama nedeniyle, gemilerin çifte tâbiiyetli olmaları olasılığı vardir.

\section{V. Çifte Vatandaşlı̆̆ın Önlenmesine Illişkin Vatandaşlık Hukuku Kurimlan}

Çifte vatandaşıık büyüik ölçüde, Devletlerin izledikleri nüfus siyasetleri, yabancı ülkelere giden vatandaşlarının ülkeden kopmalarını önleme çabaları sonucunda ortaya çkmaktadır. Devlet, bir yandan ülke dişında oturmasına rağmen iulke kïltürüne bağlı olan kişileri kollamak, diğgr yandan ülkeye yerleşmek niyetiyle gelen 
kişilerin sayılarının artmasını önlemek görevlerini yerine getirirken vatandaşlık hukukunun olanaklarından yararlanmaktadır. Kişinin ülkesine gittiği yabancı Devlet ise, yabancı sayısını olanaklar el verdiği ölçuide azaltma çabasındadır. Bu karşılıklı çıkar çatışmalarını yumuşatmak ve bireylerin iradelerine daha geniş serbesti tanımak amaçları ile vatandaşık hukuku bazı kurumlar getirmeyi zorunlu görmüştür. Bu getirilen kurumlar arasında Seçme Hakki önemli yer tutmaktadır. Seçme hakkı, bu hakkın tanındığı insan gruplan açısından ele alınabilir.

Evlenme veya nesep bağ nedeniyle çifte vatandaşlığa kavuşanlar açısından tanınmış olan seçme hakki, vatandaşlık çatışmalarını önleyen kurumlar sıralamasında önde gelen yeri tutar. Nesep alanında seçme hakkı, doğumla çifte vatandaşlığı kazanmış olan çocuğun, reşid olmasından başlayarak iki vatandaşlığından birisini seçebilme yeteneğidir. Çocuğun seçme hakkını kullanma yetkisi belli bir süre ile, örneğin iki veya ïç yıl gibi sınırıdır. Bu yoldan, herkeșin vatandaşlığını iradesi ile seçmekte hür olduğu prensibinin somut bir örneği verilmektedir. Seçme hakkının ikinci bir türü, evlenme ile çifte vatandaşığı kazanmış olan kadına, boşanma veya ölüm nedenleriyle evlenmenin sona ermesi hallerinde tanınmıştır. Boşanmış veya dul kalmış olan kadın, belli bir süre içinde seçme hakkını kullanarak çifte vatandaşlıkları arasında seçim yapma hakkına sahiptir. Ahalî müdahalesi, arazi terk ve ilhâkı hallerinde ortaya çıkan hiyar hakkı (opsiyon) vatandaşlık hukuku dışında, uluslararası sözleşmelerle düzenlenmiştir. Hıyar hakkı vatandaşlık hukukunda yer alan seçme hakkından farklıdır. Burada, çifte vatandaşığın ortadan kaldırnlmasından çok, bireyin yaptığı ilk seçimi değiştirmesi hakkı söz konusudur. Hıyar hakkı bireye yaptığı bir seçimden cayma olanăğ getirmektedir.

Kişinin kendi iradesi ile çifte vatandaşlığı sona erdirmesi için getirilen bir diğer kurum çıkma'dır. Çıkma'nın, seçme hakkı gibi bir hak olup olmadığı tartışılabilir. Herkesin vatandaşlığını seçmekte serbest olduğu ve herkesin yalnız bir vatandaşlığı olması gerektiği prensipleri açısından konu ele alınırsa, çıkma kişi açısından bir hak olmalıdır. Karşıı olan düşüñnceye göre, çıkma, seçme hakkkı gibi salt irade beyanı ile gerçekleşen bir hak değildir. Devletin takdir yetkisini kullanarak, irade beyanı ile gerçekleştirilmek istenen vatandaşlıktan ayrılmaya izin vermesi gereklidir. Devletin çıkma alanında ki takdir yetkisi egemenlik hakkının bir sonucudur. 
Feodal dïzende, bireyin vatandaşlığını değiştirmesi nedeniyle ortaya çıkan senyörün kayıplarını, kısmen de olsa karşılayan bir bedelin ödenmesi, çoğu kez öngörülmüşstür. Malı saydığı insanı sömüremediğinden ekonomik kayba uğrayan senyörün bu kaybı karşlanmalıdır. Bireyin bizzat kendisi veyahut onun ikametgâhını taşıdığı yeni ülke, senyörün kaybını dengeleyecek bir bedel ödeyecektir. Prusya Devleti, herkesin vatandaşlığını değiştirmekte serbest olduğu ilkesine dayanarak çıkmayı düzenlerken, feodal anlayışın etkisiyle, bireyden askerlik yükümü adı altında bir bedel istemiştir. Prusya, Alman birliğini gerçekleştirmenin askerî gücü gerektirdiğini ve çağdaş Devletin varlığını koruyabilmesinde askerlik yükünün önemli yeri olduğunu kabul etmiştir. Alman Birliği sağlandıktan sonra, askerlik yüikümü ile vatandaşlık arasındaki ilişki Almanya'da istikrarlı bir çizgi içerisinde kalmamıştır. Örneğin, 1920-1932 döneminde askerlik yükümü ile vatandaşlık arasındaki bağ tamamen kopmuştur $^{24}$.

Çifte vatandaşlı̆̆ı olanlar açısından askerlik yükümünü iki kez yerine getirme olasılığı vardır. Bunun önüne geçmek için bulunan yol, çifte vatandaşlık halinde, Devletlerden birisinde askerlik hizmetini yapmış olmak yeterli sayılmaktadır. 1111 sayıli Askerlik Yasası'nı değiştiren 21.5.1992 tarih ve 3802 sayılı yasa bu yöndeki uygulamaya bir örnektir. Çifte vatandaşlığı bulunan bireyin vatandaşı olduğu Devletlerden birisinin muvvazzaf askerlik hizmetini öngörmemesi halinde, diğer Devletin bireye askerlik hizmetini yaptırmak istemesi olasıdır. Çağdışı sayılma hali de, ülkeler tarafından farklı düzenlenmiş olması nedeniyle ayn bir sorundur. Konuyla ilgili bir üçüncü sorun da, vicdanî inanışlar nedeniyle askerlik yükümünü yerine getirmeyi reddetmek $\cdot$ hakkıdır ${ }^{25}$. Askerlik yükümüne ilişkin tüm bu konularda çifte vatandaşlığa sahip olan kişinin statüsü hangi vatandaşlığına göre düzenleneceği, kişi açısından önemli bir sorundur. Önsorun niteliğindeki bu sorunların çözümünde lex fori, gerçek vatandaşlık ve ikametgâhın bulunduğu Devlet vatandaşhğı çözïmleri hatıra gelmektedir. Bireyin ikametgâhı vatandaşlığı öncelik taşımalı, bunun bulunmaması halinde gerçek vatandaşliğa yönelinmelidir.

24. Schaetzel, age., s.205.

25. Mieville (Çev. Alnak), Vicdanî Inanışlarim hleri Sürerek Askerlik Mükellefiyetini Yerine Getirmeyi Reddetmek Kanun Tarafindan Cezalandinimalı midir?, Mukayeseli Hukuk Araștımalan Dergisi, Y1l 7, S.10, 1973, s.103-114'de konuya ilişkin ge. nel bilgiler vardır. 
Aynı zamanda ikamet ettiği yabancı ülke vatandaşı da olan bir Türkün çıkma istemi, T.V.Y. md. 20/b açısından incelenirken Türk vatandaşlığı kadar yabancı ülke vatandaşlığı da göz önüne alınmalıdır. İkametgâhının bulunduğu Devlet yasalarına göre askerlik yapmış sayılan veya çağdışına çıkmış olan veyahut vicdanî inanışlarını ileri sürerek askerlik yükümünü reddeden Türk hakkında, lex fori değil ikametgâh yasasına göre karar verilmelidir. Belirtilen konulara ilişkin bir düzenleme T.V.Y. veya 2675 sayılı DHH yasasında veya askerlik yasalarında bulunmadığından sonuca yorum yoluyla varılması gereklidir.

Kaybettirme, çıkarma ve vatandaşlığa alınmanın iptali kurumlan genelinde çifte vatandaşlı̆̆ı önlemeye yönelik değildir. Belirtilen kurumların ana amacı, hakkın kötüye kullanılmasını önlemek ve Devletin varlığı ile güvenliğini korumaktır. Çifte vatandaşlığı önleyici nitelikte bir hükme kaybettirme halinde rastlanmaktadır. Izin almaksızın yabancı Devlet vatandaşı olan Türk, yetkili makam karan ile Türk vatandaşlığını kaybedebilir. T.V.Y. md.25/a hükmü, vatandaşlık hukukunun Ortaçağdan günümüze kadar gelmiş olan bir düzenlemesidir.

Devletler geçen yüzyıldan beri uluslararası andlaşmalarla çifte vatandaşlığı önleme çabası göstermişlerdir ${ }^{26}$. Çabalara ilişkin yeni bir örnek, Strasbourg'da imzalanan 6.5.1963 tarihli Çok Vatandaşlık Hallerini Azaltmaya ve Çok Vatandaşlık Halinde Askerlik yükümüne Dair Avrupa Konseyi Konvansiyonudur ${ }^{27}$. 1930 Lahey Sözleşmesi vatandaşlık çatışmalarını çözümlemeyi amaçlamakta, 1963 Strasbourg Konvansiyonu ise çifte vatandaşlığı önleme çabasındadır. Konvansiyonun üç ana amacı vardır. Vatandaşlık hukuku alanında kadın erkek eşitliğini gerçekleştirmek, ailede tâbiiyet birliğini sağlamak, nihayet karma evlilik (mariage mixte) alanında yer alan çifte vatandaşlık ve vatansızlık hallerini önlemektir.

Konvansiyonun ilk maddesinin birinci bendine göre, âkit Devletlerin reşit vatandaşları açık irade beyanı sonucunda telsik, seçme hakkı veya tekrar iktisap yollarıyla bir diğer âkit Devlet vatandaşl1ğını kazanmaları halinde önceki vatandaşlıklarını kaybederler. Önceki vatandaşlıklarını koruma hakkı tanınamaz. Mümeyyiz veya reşid olmayan kişiler de, veli veya vasilerinin izni ile telsik, seçme

26. Konvansiyon ömekleri için bkz. Berki, age., s.34-36.

27. Konvansiyon hakkonda kısa bir bilgi için bkz. Documents-Conseil De l'Europe, Annales De La Faculté De Droit D'Istanbul, Tome XVII, Nos. 26-27-28- Istanbul 1967, s.592.597. 
hakkı veya tekrar iktisap yollarıyla âkit Devletlerden birisinin vatandaşlığını kazandıkları takdirde, önceki vatandaşlıklarını kaybederler. (Konvansiyon md.1/2). Ana ve babanın vatandaşliklanını değiştirmelerinin çocuklar üzetindeki etkisi Strasbourg Konvansiyonu md. $1 / 3$ 'de düzenlenmiştir. Cocuklar, kural olarak ana ve babalarn$\mathrm{nt}$, önceki vatandaşlıklarını kaybetme koşulu ile izlerler.

Konvănsiyonun ikinci maddesine göre, âkit Devletin izni ile kişi çifte vatandaşlıklarından birisinden ayrılabilir ve bu suretle yalnız bir vatandaşliğa sahip olabilir. İzin keyfiyeti âkit Devletin takdirine bağlıdır. Akit Devlet bireyin, en az on yıldan beri vatandaşlığını korumak istediği ülkede mûtaden bulunuyorsa izin istemini reddedemez. Konvansiyon, Avrupa Konseyi üyeleri arasında dahi gerekli uygulama ve etkinliği bulamamıştır. Uygulama, çifte vatandaşlığı önlemek yerine onun yol açtığı ihtilâfları çözmeye çalışmanın daha akıllıca bir yol olacağını göstermiştir.

\section{VI. Çifte Vatandaşlik ve Önsorun}

Somut olayda uygulanan vatandaşlık yasası, olayda yer alan ana sorunun yani kişinin Türk vatandaşliğın kazanması için, diğer bir yasa hükmü tarafindan düzenlenmiş olayın örneğin evlenmenin hukukî sonucunun varlığını aramaktadır. Önsorun, vatandaşık yasasına dayanarak, kişinin ilgili Devlet vatandaşlığını kazandığına veya kaybettiğine hüküm verilebilmesi için gerekli olan ve hukuki sonucu doğmuş bulunan bir hukukî olgunun varlığını gerektirir. Önsorun'a konu olan hukukî olgunun varlığı ve hukukî sonucu, vatandaşlık yasalarınca veya diğer başka yasalarla hükme bağlanmı̧ olabilir.

T.V.Y. md.6 Genel Olarak Vatandaşlığa Alınma (Adî Telsik) kunumunu düzenlemektedir. Hükmün $b$ bendine göre Türk vatanda\$̧l olmak isteyen yabancının ülke'de başvuru tarihinden geriye doğru 5 yıl ikamet etmiş olması gerekir. Yabancının ikameti önsorun niteliğindedir. T.V.Y. bu önsorunu, genel yasaların dışında kendisi md.9'da özel olarak düzenlemiştir. Yabancı kişinin Türkiye'de bulunmasının ne suretle hukukî sonuç doğuran bỉ olgu olduğu hükme bağlanmaktadır. T.V.Y. hükmünün bulunmadığı dönemlerde yabancının ülke'de ikameti olgusu genel hükümler içerisinde düzenlenmekte idi.

Önsoruna ilişkin iki örnek daha verilecektir. Avusturya'l olan bir kadın ile Alman erkeğinin evlilik içinde doğan çocukları, baba- 
nın Alman vatandaşlığını kazanmıştır. Çifte vatandaşlığı sınırlama amacını güden Avusturya yasalarına göre, T.V.Y.'den farklı olarak, çocuğun ananın Avusturya vatandaşlığını kazanıp çifte vatandaşhıga sahip olabilmesi için, ebeveynin rızası gereklidir. Baba iradesini belirleyecek dilekçeyi imzalamamaktadır. Bu halde de, ortada bir önsorun vardır. (Sonuca ulaşabilmek için karş. 2567 sayılı yasa md.19, 15, 12). İkinci örnek ise, evlenmenin ölümle sona ermesi ve gaiplik halleri T.V.Y. md. 13 ve 28 açısından önem taşımaktadır. Türk Medenî Yasası md.43'e göre yargı̨̧ Türk vatandaşının gaipliğine karar verir. Alman ve Avusturya hukuklarına göre ise kaybolan kişinin, belli bïr sürenin geçmesi koşulu ile yargıç ölümüne karar verir. Kaybolan bireyin ölüm tarihi, gaiplik kararı halinde ölüm kararı halindekinden farklı olabilmektedir. Hayatta kalan eşin seçme hảkkını kullanabilmesi için, Alman ve Türk vatandaşlıklanına sahip kocanın ölüm tarihin saptanması bir önsorundur.

Vatandaşlık hukuku hükümlerinin, diğer hukuk dallannın getirdiği kurum ve kavramlardan yararlanarak önsorun'a yol açtığı hallerin örneklerine sık rastlanmaktadır. Rum Ortodoks dinine mensup ve Türkiye'de mukim bir Türk vatandaşının, Yunanistan'da oturan ve Yunan vatandaşı olan bị kadınla Atina'daki kilisede din̂̂ törenle evlenmesi halinde, Yunanlı kadının T.V.Y. md. 5'e göre Türk vatandaşlığını alabilmesi ana sorundur. Yunanistan'da resmî nikâh değil, kilisede papazın yaptığı evlilik geçerlidir. Yapıldığı yer yasalarına göre hukukî sonucu doğmuş bulunan evlenmenin Türkiye'de geçerliği önsorundur.

Vatandaşlık hukuku'nda ortaya çıkan önsorun hakkında, T.V.Y. Türk yasası olduğuna göre, Türk mevzuatına göre karar verilecektir. Türk mevzuatı olarak, yalnızca Türk maddî iç hukuku kabul edilirse, Medenî Yasa md.110 hükmü uygulanacak ve dinî törenle yapılan evlenme, kamu düzeninden sayılan hükme aykırı olduğundan geçerli sayılmayacak ve bunun sonucunda kişiye vatandaşlık verilmeyecektir. Türk mevzuatı kavramını yukarıdakinden farklı bir düzeyde de niteleme olasıdır. Türk mevzuatı daha kapsamlı düşünülür ve maddî iç hukuk kurallarının yanında Yasaların Çatışması kurallarını da kapsar hale getirilirse, 2675 sayılı DHH yasası md.6'ya göre, Yunan Devletinin öngördügüü biçim koşullarını yerine getiren evlenme geçerli ve Yunan kadını Türk vatandaşı olacaktır. Locus regit actum kuralına dayalı bu sonuç uygulamada geçerlidir. 
Belirtilen sonuç gerçekte hatalıdır. Lâik bir Devlet olan Türkiye'nin Locus regit actum kuralına göre evliliğin geçerliğini kabul edebilmesi için, kilisedeki papaza evlendirme yetkisi veren bir Yunan yasasının bulunması gereklidir. Papaz, kendisine evlendirme memuru yetkisi veren bir hüküm bulunmadan nikâhı kıymaktadır. Yunanistan ve onunla aynı yönde olan İspanya yasaları papazlara evlendirme memuru yetkisi veren bir hüküm getirmemişlerdir. Yunan ve İspanyol anlayışına göre, Papazın evlendirme memuru yetkisi tanri'nın bir emridir. Locus regit actum kuralının, çağdaş yüzyılda tanrı emirlerini kapsadığını kabul etmek güçtür.

Bu genel açıklamalardan sonra, bizatihi çifte vatandaşlığın kendisinin önsonun olduğu hallere de değinilmelidir. llk örnek, Türk vatandaşı ile evli olan kadının evliliğin sona ermesinden sonra, T.V.Y. md.28'e göre seçme hakkını kullanarak Türk vatandaşlığından aynılmasıdır. Seçme hakkını kullanarak Türk vatandaşlığından ayrılma ana sorundur. Seçme hakkından yararlanabilmesi bir başka hukukî olgunun varlığını, kadının halen yabancı Devlet (Yunan) vatandaşlığına sahip olmasını gerektirmektedir. Kadın halen Yunan vatandaşı ise, iradesini kullanıp evlenme ile kazandığı Türk vatandaşlığını terk edecektir. Çifte vatandaşlığın önsorun olmasının örneklerine T.V.Y. md. $20 / \mathrm{c}$ ve $25 / \mathrm{a}$ hükümlerinde de rastlanmaktadır. Türk vatandaşığını kaybetmek çifte vatandaşlığın varlığı olgusunu gerektirmektedir.

Vatandaşıı yasası dışında da çifte vatandaşlık önsorun olmaktadır. Örneğin, 2567 sayılı yasa md. 32 fikra 2 hükmüne göre, Türk mahkemelerinde dâva açan yabancı karşılıklı olmak koşulu ile güvence (teminat) gösterme băğşıklı̆ğından yararlanır. Dâvacı yabancının, çifte vatandaşı̆̆g olması ve bu Devletlerden birisi ile Türkiye arasında karşılıklılık bulunması halinde kişi lehine bağışıklık doğacaktır. Örneğin, Alman ve Arjantin vatandaşlklarına sahip kişinin 2675 sayılı DHH yasası md.4/c'ye göre Alman sayılması halinde, Sözleşmelere dayanarak güvence yükümü doğmayabilir. Fakat, ay$\mathrm{nı}$ kişinin Arjantin vatandaşı sayılması halinde güvence yükümü doğacaktır.

Çifte vatandaşlığın önsorun olmasına ilişkin bir başka örnek muvazzaf askerlik hizmeti alanında görülmektedir. 1111 sayıl Askerlik yasasının, 3802 sayı ve 21.5.1992 tarihli değişik hükümlerine göre, çifte vatandaşlığı olan Türklerin yabancı ülkede yaptıkları askerlik hizmetinin, belli koşullar ile Türkiye'de de sayılması gere- 
kir. Konu ile ilgili olarak, Avrupa'da bulunan ve çifte vatandaşlığı olan Türkleri ilgilendiren örneklere değinilecektir. Çifte vatandaşlığı olan ve yurt dışında ikamet eden Türk'ün çağdışı sayılması bir önsorundur. Bu önsorun hakkında karar verirken lex fori'den hareketle Türk vatandaşlığı esas alınırsa, birey uzun bir süre daha askerlik yükümü ile karşı karşıyadır. Buna karşılık, ikametgâhının bulunduğu ve ikamet ettiği diğer ülke, örneğin Alman vatandaşlı̆̆ı esas alınırsa, kişi çok daha kısa bir süre sonra çağdışına çıkmış sayılacaktır. Aynı biçimde, çağdışı sayılmanın yanında askerlik yükümünden kaçma yani asker kaçağı sayılma nedenlerinin de hangi vatandaşlığa göre saptanacağı bir önsorundur. Yanıt, 2675 saytlı DHH md. 4/b'ye göre aranacak olursa lex fori yani Türk vatandaşl1ğı esas alınacaktır. Bu anlayışın karşısında, 1930 Lahey Konvansiyonuna ilişik Çifte Vatandaşlığı Olanların Askerlik Yükümüne İlişkin Bazı Sorunları Düzenleyen Protokolün l'nci maddesi yer almaktadır. Bireyin mûtaden bulunduğu ülkenin vatandaşıı̆ğ, en sıkı bağının (irtibatını) bu ülke ile olması koşuluna bağlanarak esas alınacaktır. Zamanla Türk uygulamasının da, sözü edilen Protokolün hükümlerini uygulayacağı ümid edilir.

Çifte vatandaşlığın varlığının kanıtlanması sorununa da değinmek gereklidir. T.V.Y. md.38/c'ye göre, pasaport ve pasaport yerine geçen belgeler, aksi sabit oluncaya kadar Türk vatandaşlığını kanitlayan belgelerdir. Aynı karineye, 5683 sayılı ve 15.7 .1950 tarihli Yabanciların Türkiye'de Ikamet ve Seyahatleri Hakkındaki Yasa uygulamasında da yer vardır. Pasaport karinesinin uygulamada sanıldığı kadar sağlam olmadığı konusuna değinilecektir.

İlk örnek Alman hukukundan getirilecektir. Alman hukukunda çıkma (Entlassung), kaybettirme (Ausbürgerung) dışında iki tür çıkarma (iskat) vardır. Adî çıkarma (Zwangsausbürgerung) ve otomatik çıarma (Automatische Zwangsausbürgerung) olmak üzere iki hal isimlendirilmektedir. Alman vatandaşlık yasası md.26'ya göre, otomatik çıkarma, asker kaçağı olan kişilere uygulanır ve asker kaçağı olduğu kararından kişi iki yılın geçmesi ile Alman vatandaşlığını kendiliğinden kaybeder. İlgininin elinde halen geçerli Alman pasaportu bulunması veyahut idarenin iskat işlemine hiç girişmemiş olması Alman vatandaşı̆ı̆ının otomatik kaybını etkilemez. Bu halde kişi elindeki Alman pasaportuna rağmen çifte vatandaş sayılamamalıdır. Vatandaşlık çatışmalarının çözzümünden önce, gerçekten çifte vatandaşlığın var olup olmadığı aranmalıdır. Bu konuda, vatandaşlığı iddia edilen Devletlerin herbirinin yasalanı ayn ayrı uygulanmalıdır. 
Konuya ilişkin bir başka örnekte Fransa'dan gelmektedir. Fransa lejyonerlere, orduda hizmet ettikleri sürece vatandaş muamelesi yapmaktadır. Lejyonerin elindeki kimlik, pasaport veya diğer belgeler geçici vatandaşlığın karinesidir. Ortaya çıkan sorun, Alman, Polonya, Sırp vatandaşlığına sahip kişilerin lejyoner oldukları sürece çifte vatandaşlığa haiz sayılıp sayılmayacaklarıdır. Bir başka sorunda, lejyonda yapilan hizmetin muvazzaf askerlik hizmetinden sayılması, çifte vatandaşın bir kez askerlik yüküimü olduğu ilkesinin kapsamında olması konusudur. Belirtilen konularda lex fori ilkesinin uygulanması gerektiği sanılmaktadır. Lejyonda görev alma taraflar arasında yapılan bir sözleşmeye dayanmaktadır. Muvazzaf askerlik hizmeti ise yasal bir yükïimdür. Lejyonerin vatandaşlıklarının birisinin Türk olması halinde de lex fori Devletinin vatandaşığı esas alınmalıdır.

Fransa'dakine benzer bir durum Amerikan ordusunda görev yapan yabancı Devlet vatandaşlan açısından da söz konusudur. Bu kişiler görev sonunda A.B.D. vatandaşlığına girmeye hak kazanırlar. Amerikan ordusunda görev yapan bir Türk'ün, A.B.D. ülkesi içerisinde ne düzeyde Türk vatandaşlığından yararlanabileceği veyahut A.B.D. dışındaki bir göreve gönderilmesi halinde çifte vatandaş sayılıp sayılmayacağı ortaya çıkan sorunlardır. Kişinin çifte vatandaşlığı olduğu kabul olunmamalı ve halen vatandaşlık bağı ile bağlı bulunduğu Devlet vatandaşlığı esas alınmalıdır.

\section{VII. Çifte Vatandaşliktan Doğan Vatandaşlık Catısmalarmın Çözümü}

Charlemagne'dan sonra, önce Frank Devleti ve sotra tüm Avrupa'da feodal düzene geçiş hızlanmıştır. İkametgâh sicilleri, şahsî hal (ahval-i şahsiye) sicilleri kadar düzenlidir. Ulkede ikamet eden herkes bir kilise cemaatine üye olarak kayıtlıdır. Kolluk kuvvetlerinin tuttuğu ikametgâh sicilleri, şahsi hal sicilleri (kilise tarafından tutulan) biribirini tamamlamaktadır. Çifte vatandaşlık önlenmekte ve tâbiiyet ihtilâflarına da rastlanmamaktadır. Feodal dïzeni tüm yönleri ile yaşamış olan İsviçre, Almanya, Fransa gibi Hristiyan Batı Avrupa Devletlerinde, halen ikametgâh kayıtları, şahsî hal sicilleri ve kilise cemaat defterleri düzenli biçimde tutulmaktadır.

Feodal düzeni ve onun Prens-Devlet anlayışını yaşamamış olan toplumlar, örneğin tüm Amerika ve Avusturalya kıtaları uygulamasında, Kara Avrupasında geçerli olan ikametgâh sicili, şahsi hal sicili ve cemaat kayıt defterleri úçlüsü bir arada bulunmamıştır. Ha- 
len, konu dünya çapında ele alındığı zaman, düzenli ikametgâh sicili ve dinî cemaat kayıtlan buhunan Devlet sayısının azlığı gözlenmektedir. Devlet genel olarak, şahsî hal sicillerini düzenli tutma çabası içerisindedir. Türkiye'de Devlet tarafından, tüm aksaklıklarına rağmen, düzenli biçimde nüfus sicili ve tapu sicili tutulmaktadır. Özellikle büyük şehirlerde mahalle muhtarlarının tuttukları ikametgâh sicilleri güvenilemiyecek ve düzensiz sayılabilecek kayıtlardır. Bölge din görevlilerinin düzenli ve güvenilir cemaat defteri tuttuklarna Türkiye'de rastlanmamaktadır. Belirtilen nedenlerin de etkisiyle Türk DHH genel olarak ikametgâh ilkesine yabancı kalmıştır.

Egemen ulusal Devlet ile birlikte vatandaşlığa yön veren ölçütler değişmiştir. Ulusal Devlet dinî nedenlerle ülke bütünluiğünü zedelenmemesi çabasındadır. Kilisenin veya din adamlarının tuttuklan kayıtlar, lâik Devlet açısından önem taşımamalıdır. Sonra, ulusal Devlet ülke savunmasının, eskiden beri denenmiş olan paralı askerlerden kurulu ordu ile sağlanamayacağı inancındadır. Emek ve sermayeyi, endüstriyel gelişmeyi sağlayacak bir denge içerisinde tutmak ulusal Devletin, yukarıda sayılanlara eklenecek bir başka görevidir. Kaldı ki, aynı ırktan veya soydan olanların aynı Devlet vatandaşı sayılması ilkesinin ulusal Devlet tarafından gerçekleştirilemeyeceği de anlaşılmıştır. Örneğin, Türk ırkından veya Cermen ırkından olan tüm insanların aynı Devletin çatısı altında toplanması dünyada var olan siyasî dengeler bakımından olanaksızdır. Ulusal Devlet vatandaşlık bağının ölçütlerini saptarken, feodal dönemdekinden daha hoşgöriülü davranmak ve çifte vatandaşlığın kaçınılmaz olduğunu görmek zorundadır.

Ulusal Devlet vatandaşlığın ölçüitlerini egemenlik hakkına dayanarak saptama yetkisini, kişinin çıkarlarnn, uluslararası dengeleri gözönüne alarak kullanmalıdır. Kişinin iradesi ile vatandaşlığını değiştirmesi konusuna yeterince önem verilmelidir. Devlet, çifte vatandaşlığın kendi güvenliğini ve varlığını etkileyen suisstimallerini önleyici hükümleri getirmek hakkına sahip olmalıdır. İngiltere'nin deneyimlerinin de gösterdiği üzere çifte vatandaşlık, suiistimalleri önleyici gerekli yasal önlemler alınması koşulu ile korkulacak bir kurum değildir. Vatandaşlık hukukunun uluslararası alanda geçerli olan ilkelerine uygun bir vatandaşlık yasası yapabilmek için hem kan ve hem de toprak bağından yararlanması kaçınılmazdır. Telsik, seçme hakkı, çıkma konularında, Devletin varlığını etkileyen sınırlı haller saklı kalma koşulu ile kişinin iradesine üstünlük tanınmalıdır. Kaybettirme vatandaşlığa alınmanın iptali, çı- 
karma gibi kurumlarla, Devletin kendi varlı̆̆ını ve güvenliğini koruma olanağı getirilmelidir. Vatandaşlık yasalarının, vatandaşlık hukuku'nun karmaşı ilkeleri ve değişik çıkarlar arasında ideal bir denge kurması çok zordur.

Sayıları ikiyüze yaklaşan bağımsız Devletlerin herbiri kendi vatandaşlık yasasını yaparken diğerinden farklı çıkar dengelerinden ve farklı etmenlerden hareket etmektedir. Hem ada Devleti, hem de sömürgeci geçmişi olan İngiltere'nin vatandaşlık yasasını etkileyen etmenler ile Osmanlı Devleti'nin miras yükü̈nü taşıyan ve yabancı ülkeye emek ihraç eden Türkiye'nin vatandaşlık yasasını etkileyen etmenler arasında önemli farklar vardır. Bu farklilıklar sonucu, Ingiliz vatandaşılık hukuku hükümlerinin vatandaş saydığı bir kişiyi, aynı zamanda Türkiye'nin de vatandaş sayması olasılığı ortaya çıkmaktadır. Belirtilmeğe çalışıldığı üzere, çifte vatandaşlık, gerçekte Devletlerin vatandasslik yasalarında ifadesini bulan farklı clkarlarının çatışması ve kişilerin iradelerine tanınan yetkiyi, haklı olarak çıkarlarına en uygun gelen biçimde kullanması sonucunda ortaya çıkmaktadır. Iki ayn Devlet yasalarının, aynı kişiyi her iki Devletin vatandaşı sayması vatandaşlık çatışmasına (tâbiiiyet ihtilâflarına) yol açmaktadır. Ortaya çıkan vatandaşlık çatışmasıııın çözümüi konusunda oybirliği yoktur.

\section{Vatandaşlik Çatı̧smalarınt tek bir kuralla çözümlemek isteyen görüşler}

Azınlıkta kalan görüşlerden birisine göre, vatandaşlık çatışmalan bir bütündür. Vatandaşlık çatışmalarında, kişinin vatandaşliklanndan birisinin yetkili makamin mensup olduğu Devlet (genel olarak lex fori) ile aynı olup olmayışına göre bir ayırım yapmağa gerek yoktur.

Seçimin temeli, kişinin sıkı organik bağının (engste organische Zusammenhang) bulunduğu Devlet ölçütüdür. Sıkı organik bağ bir olgular demetidir ${ }^{28}$. İkametgâh, seçimde oy verilen yer, ailenin mûtaden bulunduğu ülke, askerlik hizmetinin yapıldığı yer, kamu görevi alınan iilke, sosyal faaliyetlerde bulunulan mahal gibi tüm olgular birarada ele alınarak değerlendirne yapılmalıdır. Bu görüşün, en önemli sakıncası en sıkı organik bağın, sürekli olarak lex fo$r i$ uygulaması eğilimine açık olmasıdır. Lex fori uygulaması, günü-

28. Ferid, Internationales Privatrecht, Berlin 1975, No. 1-34, s.9; Kegel, age., s.177. 
müzde çifte vatandaşlığı olan birey aleyhine önemli sakıncalan beraberinde getirmektedir. Kaldı ki, en sıkı organik bă̆ kavramına dayanarak bulunacak vatandaşlık yargıcın sübjektif bir değer yargısıdır. Sübjektif değer yargısından önce kesin bağlama yöntemleri denenmelidir.

Common law'da vatandaşlik çatışmalarının çözümünde ayırım yanlısı değildir. İngiliz hukuku, vatandaşlık çatışmalarının çözümünde, genel anlayışına uygun olarak, bireyin ikametgâhının bulunduğu Devlet vatandaşlığını yeğlemektedir. Örneğin, Türk ve İngiliz vatandaşlıkları bulunan ve Türkiye'de ikamet eden bireyi, Ingiliz yargıcı Türk kabul edecek ve Türk yasalarını uygulayacaktır. Ayn biçimde, İngiltere'de ikamet eden ve İngiliz vatandaşlı̆̆ da bulunan bir Türk'ü İngiliz yargıcı Ingiliz vatandaşı kabul edecek ve İngiliz yasalarnnı uygulayacaktır. Aynı biçimde, Ingiltere'de ikamet eden ve Ingiliz vatandaşlığı da bulunan Türkü, Türk yargıcı Ingiliz vatandaşı kabul edebilmelidir. İngiliz yasalarına göre, çağdışına çıkmıs olan, fakat Türk yasalarına göre askerlik yükümü bulunan veya vicdanî nedenlerle askerlik yükümünü reddeden Türk'ï Türkiye askere alamayacaktır. Türk hukuku belirtilen sonuca ulaşacak hükümleri getirmemiştir.

\section{Vatandaşlik Çatışmalarının Bir Ayırmma Giderek Çözümleyen Görüis}

\section{a) Lex fori kuraima giren haller}

Vatandaşlık çatışmalarında, konuyu bölerek ve lex fori'nin çıkarlarını gözeterek çözüm getirilmesini sağlayan görüş uygulamada daha başarılı olmuştur. Çoğunluk görüşüne göre, vatandaş̧ık çatışmalarının çözümü alanında bir ayırıma gidilmelidir. İlk önce, kişinin vatandaşlıklarından birisinin sorunu çözümleyecek olan Devlet vatandaşlıklarından olup olmadığına bakılmalıdır. Kişinin vatandaşlıkłarından birisinin, sorunu çözümleyecek makamın mensup olduğu Devlet vatandaşlığı olması halinde, işbu Devlet vatandaşlığı esas alınır ${ }^{29}$. Bir makamın önünde, çifte vatandaşlğğ öne sürülmesi halinde, yargıç önce ileri sürülen Devlet vatandaşlıklarından birisinin lex fori ile aynı olup olmadığını saptayacaktır. İleri sürülen Devlet vatandaşlıklarından birisinin lex fori Devleti ile aynı olması halinde mahkemenin (veya makamun) mensup olduğu Devlet vatan-

29. Ferid, age., s.9; Schaetzel, age., s.127 ve 67; Kegel, age., s.177; Uluocak, age., s.16; Nomer, Vatandaşlik Hukuku Dersleri, İstanbul 1976. s.26; Wolff, Das Internationale Privatrecht Deutschlands, Berlin 1954, s.41. 
daşlığı esas alınacaktır. Lex fori'nin üstünlüğü, vatandaşlık yasası hükümlerini Devletin egemenlik hakkına dayanarak koymuş olmasıdır. Aynı hükümler Devletin uluslararası alandaki çıkarlannı da ilgilendirmektedir.

Vatandaşlık çatışmalarının çözümünde an'asıl vatandaşlık, aslî tâbiiyet, doğumla kazanılan vatandaşlık (original nationality) ile sonradan kazanılan vatandaşlık (müktesep tâbiiyet -yeni vatandaşlık- new nationality) arasında bir öncelik yoktur. Çifte vatandaşlık dâva tarihinde var olmalıdır. (2675 sayılı DHH yasası md.3 ile kar§̧1.). Dâva görülmekte olduğu sırada ikinci bir Devlet vatandaşlığınt, örneğin Türk vatandaşlığını kazanan yabancının, md.3 nedeniyle, Türk maddî iç hukukunun uygulanmasını isteyememesi olumlu karşılanamaz. Türkiye'de ikamet eden ve dâva açıldığı zaman İngiliz vatandaşı olan Türk soyundan kişinin, dâva sırasında Türk vatandaşı olması halinde, Türk iç hukuku yetkili olabilmelidir. Buna karşılık, dâva açıldığında vatandaşlıklanından biri Türk olan kişinin, dâva sırasında Türk vatandaşlığını kaybetmesinin 2567 sayılı DHH yasası md.3'e rağmen, en azından md.32'deki güvence (teminat) yükümü açısından sonuçları olmalıdır. Türk vatandaşlığından dâvanın görülddügüi strada ayrilmış olan kişiye halen Türk yasalarnnın, çifte vatandaşlığa sahip olduğu dönemdeki nedenlerle uygulanmasinda direnmek hatalıdır ${ }^{30}$.

Lex fori'nin uygulanması salt nitelikte değildir. Bu alanda yer alan ilk sınırlandırma önsorun halinde ortaya çıkmaktadır. Evlilik içinde doğan ve babasının vatandaşlığını alan çocuğun, yabancı Devlet vatandaşı olan anasının vatandaşlığını alabilmesi için, babanın rızasının arandığı halde doğmaktadır. Babanın rızasını verip vermeyeceği kendi vatandaşlığına bağlıdır. 1963 tarihli Çok Vatandaşlık Hallerini Azaltmak ve Çok Vatandaşlık Hallerinde Askeri Hizmetlere Dair Strasbourg Sözleşmesinin/IV ve 2/III maddeleri de belirtilen yöndedir ${ }^{31}$.

1930 Lahey Sözleşmesi md.1'e göre Uluslararası Sözleşmeler

30. 2527 sayılı yasa md. 3 'e göre çalışma izni alanların güvence yükümü̈nden kurtulmaları gerekir. Buna karşılık, tüm variı̆ın Yunanistan'a götürmüiş olan, ancak halen Tïrk vatandaşlı̆̆ından aynlmamış olan kişi Türk mahkemelerinde açacağı dâvada güvence göstermelidir.

31. Alman, Isviçne, Türk hukukları mahfuz hisseyi tanımaktadır. Ingiliz ve Amserikan miras hukuklan mahfuz hisseye yer vermemektedir. Alman ve Ingiliz vatandaşlıklarina sahip olan ve Ingiltere'de mukim bulunan bir müteveffanin, mahfuz hisseyi gözönüne almadan yaptığı ölüme bağlı tasarntun hüküim ifade etmesi önce vatandaşlık çatışmasımun çözíimínì gerektirir. 
ve teamül de lex fori uygulamasına sınır getirebilir. Çifte vatandaşlığı olan diplomatik ajan gönderildiği Devlette, gönderen Devletin diplomatik misyon'unun üyesi olarak bağışıklık ve ayrıcalıklardan yararlanır. Diplomatik misyon üyesinin vatandaşlıklarından birisinin gönderilen Devlet vatandaşlı̆̆ı olması halinde lex fori değil, gönderen Devletin yasaları yetkilidir. Bu halde, 1961 tarihli Diplomatik Illişkiye ve Bağışıklığa Dair Viyana Sözleşmesi md.43/b'ye göre, gönderilen Devletin elinde bulunan tek olanak, çifte vatandaşlığı olan diplomatik ajanı, yabancı Devletin misyonu'nun diplomatik personeli üyelerinden kabul etmemektedir ${ }^{32}$. Gönderilen Devlet tarafindan, yabancı Devletin diplomatik ajanı istenmeyen insan (persona non grata) sayılmaktadır. Örneğin, Türk ve Amerikan vatandaşlığı bulunan ve Türkiye'deki A.B.D. diplomatik misyonu personeli üyesi bulunan görevli Türk vatandaşı sayılarak hakkında lex fori uygulanamaz ${ }^{33}$.

Diplomatik misyon personeli üyesi olan görevlinin ailesi de, kural olarak tüm bağışıklık ve ayrıcalıklardan yararlanır. Aile fertlerinin çifte vatandaş olması ve bu vatandaşlıklardan birisinin gönderilen Devlet vatandaşlığı olması halinde, 1961 Viyana Sözleşmesi md.37/1'e göre lex fori uygulanır ${ }^{34}$. Yenilgi sonunda ïlkeye gelen yabancı işgal kuvvetleri askerleri veya sivil görevliler arasında çifte vatandaşlığı olanlar ve aileleri hakkında lex fori uygulanamaz. Ikinci Dünya savaşından sonra Almanya'ya işgal kuvvetlerinin üyesi olarak gelen ve Alman-Amerikan vatandaşlığına sahip olan kişiler hakkında Alman yasaları uygulanamamıştır.

1930 Lahey Sözleşmesi'nin tanıdığı diğer bir istisna ise, vatandaşlık hukuku'nun genel ilkeleridir. Kişinin rızası hilâfına vatandaş sayılması, vatandaşlık hukuku'nun genel ilkelerine aykırıdır. Örneğin, bir Devletin (Fransa'nın) himayesi altında bulunan, fakat uluslararası kurallara göre ïlkesinden sayılmayan bir ülkede (Tunus'ta) doğan ve ikamet eden yabancılan (İngilizleri) rızalarını almadan Fransız vatandaşı sayması, vatandaşlık hukuku'nun temel ilkelerine aykirıdır $^{35}$.

32. Çifte vatandaşlığın göreceli, dúkzensiz veya örtílï olması hallerini Viyana Sözleşmesi gözönüne almamaktadir.

33. NATO karargâhının statiisüne dair Protokol'tin 2/b maddesine göre (20 Mart 1954 tarihli Resmî Gazete No.8663) lex fori'ye sinurlama getirmektedir.

34. NATO karargâh protokolü es, çocuk ve ana, babayı kapsamaktadır (md.2).

35. Ingiltere'nin itirazı ïzerine konuyu inceleyen Lahey Adalet Divanı Fransa'nın konuya ilişkin vatandaşlik karamamesini yerinde bulmuş ve Ingilizlerin çifte vatandaş̧1- 
Lex fori'nin, Devletin çıkarlarına hizmet ettiği ve verilen hükmün yabancı ülke'de geçerliliğini gölgelediği bilinen eleştiridir. Bu haklı eleştirileri bilen, 1930 Lahey Sözleşmesi'nin daha iyi bir çözüm bulamadağı da gerçektir. Lex fori'nin sakıncalarını hafifletmek için istisnaların sayısını ve kapsamını genişleterek adalete hizmet etmek görünen çtkar yoldur.

\section{b) Lex Fori dısında kalan haller}

Kişinin vatandaşlıklarından hiçbirisinin lex fori olmaması halinde, Common law ikametgâh veya mûtaden bulunụlan yer Devlet vatandaşhı̆gna öncelik tanımaktadır. Common law'un hem yasaların çatışması, hem de vatandaşhı çatışmalarında uyguladığı ikametgâh veya mûtaden bulunulan yer yasası kuralı bu konuda, göreceli olarak varlığinı sürdürmektedir. Common law'dan esinlenerek çözüm getirdiği izlenimini veren 1930 Lahey Sözleşmesi değişik yorumlara elverişlidir. Sözleşme md.5 hükmüne göre, bireyin ülkesinde ikamet ettiği ve mûtaden bulunduğu veya içinde bulunduğu hal ve koşullar itibariyle en sıkı bağlı olduğu Devlet vatandaşlığı hüküm ifade $\operatorname{eder}^{36}$.

\section{aa) Tek çözüm yanlısı yorum}

1930 Lahey Sözleşmesinin 5'inci maddesi hiç ayırım yapılmadan gerçek vatandaşlik, fiili vatandaşlik, edimli vatandasslik (effektive Staatsangehörikeit-nationalité active-natinalité effective) ilkesine dayanarak uygulanmalıdır. Iki Devlet vatandaşı̆̆ı arasında seçim gerçek vatandaşlı ölçütüne dayanarak yapılacaktır ${ }^{37}$. Somut olguda bireyin içinde bulunduğu fiilî hal, olumlu olumsuz tüm yön-

ğını onamuştır. Divan, koruma altındaki ülke'de bulunan yabancıların vatandaşlığına ilişkin Fransız mevzuatını korumayı düzenleyen uluslararası sözleşmeye dayandığınu kabul etmiştir. Karş., Batiffol, age., No.89, dipnotu 49; Parry, age., s.255; Makarov, age., s.62, 161 vd.; Wollf, age., s.39.

36. Itametgâh kavram lex originis ve lex domicilii diye ikiye ayrılmaktadır. Her ikisi de Roma hukukundan gelen kavramlardır. Origio, bireyin đoğduğu, hürriyetini kazandığı veya vatandaş olduğu şehirdir. Origio zamanla deł̧işikliğe ugramuştır. Lex originis, doğum yerini değil, doğum anında bireyin ana ve babasının ikametgâhı anlamm kazanmuştır. Common law, ius originis'den hareketle domicil of origin (dozum zamanındaki ikametgâh) kavramun getimiștir. Lex domicilii ise, bireyin bütün işlerini gördüğĭ yer yasasını anlatmaktadır. DHH açısından ikametgâh ayrı bir inceleme konusu olsa gerektir.

37. Ferid, age., s.9; Kegel, age., s.177; Wolff, age., s.42; Batiffol, age., No.82. Kazanılmuş haklar kuramma dayanarak ilk elde edilen vatandaşliktan hareket edilmesi de istenmiştir. 
leriyle göz önüne alınmalıdır. Konuşulan dil, üye olunan klüp veya dernek, eğitim alınan ülke, ikametgâh, mutâden bulunulan yer, seçime katılınan yer, fiilen çalışılan ülke gibi somut olgular demetinden hareketle yargıç edimli vatandaşlığı bulacaktır. Gerçek veya edimli vatandaşılık kuralına dayanarak seçilecek Devlet vatandaşlığının, ülkede ilgilinin ikamet etmemesi halinde, diğer etmenlere dayanarak yapılacak seçiminin geçerli olacağı şüphelidir. İlgilinin ikamet ettiği veya mûtaden bulunduğu Devlet vatandaşlığına üstünlük tanımak uluslararası teamüllün de bir gereğidir. İkamet edilen Devletin egemenliği önde gelmelidir.

\section{bb) Ayırim Yanlisi Olan Yorum}

Ayırım yanlısı olan anlayışa göre, 1930 Lahey Sözleşmesinin yorumunda ikametgâh ilkesi ihmal edilmemelidir. Ayırımın ilk parçası, bireyin ikametgâhının bulunduğu yer izerinde egemenlik hakkına sahip Devletin vatandaşlığına ïstünlük tanınması ilkesidir. Bireyin ikametgâhının bulunduğu veya mûtaden oturduğu yer, vatandaşlı̆̆ını iddia ettiği iki Devletten birisi ülkesinde ise, o ülke vatandaşlığı esastır.

Ikametgâhın veya mûtaden bulunulan yerin vatandaşlık bağı ile bağlı olunan Devletlerden birisinin ülkesinde bulunmayıp bir üçïncü ülkede bulunması halinde kişinin, edimli (fiilî) olgulara göre en fazla bağlantı (sıkı irtibat) halinde olduğu Devlet vatandaşlığı esas alınır. Sözleşmenin (Konvansiyonun) bu dùzenlemesi, İngiliz Hukuku'nda birincil vatandaşllk veya üstün vatandaşllk veya önder vatandaşlik (principle of the master-nationality) kurumu olarak adlandırılmıştır ${ }^{38}$.

Devletlerin vatandaşlık yasalarını, somut olayda yer alan ilişkiler demetinden hareketle birincil ve ikincil diye derecelendirmek, yalnız olaya özgï bir sıralamadır. Bu sıralama bir Devletin egemenliği, genel olarak diğerine üstïn tutmak anlamını taşımamaktadır. Yaplan tercih, yalnız somut olaya özgü ad hoc bir düzenlemedir. Sıkı irtibat, somut olayda geçerli ilişkiler demetine dayanarak yargıç veya yetkili makam tarafından saptanacaktır.

Yetkili makamun veya yargıcın kişinin vatandaşlıklarından birisini seçmesi eş ve çocukları etkilememelidir. Aynı olayda çifte va-

38. Parry, age., s.270. 
tandaşlığı olan eş açısından yetkili makam veya yargıcın, A ve B Devletleri vatandaşı olan eşlerden, karıyı A ve kocayı B Devleti vatandaşı sayması olasıdır. Örneğin, Türk ve Hollanda vatandaşı eşlerin, Alman yargıcı tarafından önder vatandaşlıkları farklı bulunabilir. Kocanın Türk, karının Hollandalı sayılması onanmalıdır. Gerçekten aslen Hollandalı olan kadının sosyal güvenliği, taşınmazları, banka ilişkileri Hollanda'da ve aslen Türk kocanın da ilişkilerine ağırlığı Türkiye'de bulunabilir. Herhalde, ailede tâbiiyet birliği ilkesine uyulması zorunlu değildir. Benzer sonuç çocuklar açısından da geçerlidir. Aynı ailenin Hollanda ve Türk vatandaşlıklarına sahip erkek çocuklarının ana ile birlikte Hollanda'da işlemlerini toplamış olması, kızın ise baba ile Türkiye'de oturması olası bir örnektir. Bu halde önder vatandaşlık, kız çocuğu açısından Türk, erkek kardeşi yönünden Hollanda vatandaşlığıdır.

1930 Lahey Sözleşmesinin 5'nci maddesi hükmüi Common law'a koşut olarak da anlaşılabilir. Sözü edilen hükme göre, çok vatandaşlığı olan kişinin, içüuncü Devletler tarafından tek vatandaşlığı var sayılmalıdır. Ûçüncü Devlet, kendisinin şahsî statüye ilişkin hukuk kurallarına halel gelmemek ve yürürlükteki Andlaşmalar saklı kalmak koşulu ile, ilgilinin mûtaden ve esas itibariyle bulunduğu veya edimli olgulara göre en fazla bağlantı (irtibat) halinde olduğu Devlet vatandaşlığına sahip sayar. Bu hüküm common law'a koşut olarak önce ikametgâh veya mûtaden bulunulan yer vatandaşlığı, bunun bulunmaması halinde gerçek vatandaşlık veya üstün vatandaşlık lehine olarak anlaşılmaktadır.

Alman mahkemesi tarafından gerçek veya üstün vatandaşlığı Hollanda olarak görülen eşin (aslen Hollanda'lı kadının) ve erkek çocuğun Türkiye'ye gelmeleri halinde yabancı işlemine tâbi tutulmamaları gerekir. Alman yargıcının, muhtemel kararı önündeki somut olay açısından geçerlidir. Türk makamlan lex fori'yi uygulayacaklardır. Bu ömek, Osmanlı Devletinin çifte vatandaşlık alanında karşılaştı̆̆ı sıkıntıları hatırlatabilir. Özellikle, önder veya gerçek vatandaşlığın Türk vatandaşlığı olmadığı konusunda yabancı mahkemelerin veya makamların sürekli kararları karşısında T.V.Y. md.25 hükmünden yararlanarak eş ve erkek çocuğun Türk vatandaşlığını kaybettiklerine karar vermek olanaksızdır. Esasen belirtilen örnek açısından kaybettirme, kişileri ülkeden koparmama amacına da ters düşecektir. Izlenecek yol, hazırlanması önerilecek olan çifte vatandaşlık yasasının öngöreceği özel sicille ilgilinin durumunu belirten bir kaydın düşülmesidir. Ingiltere'nin yaptığı gibi bireyin çifte va- 
tandaşlığını kötiiye kullandığının yargı kararı ile saptanması halinde T.V.Y.'ye getirilecek özel bir hükümle kaybettirme yolu açılmalidir.

Lex fori'nin uygulandığı hallerde geçerli olan istisnalar, her iki vatandaşlığın üçüncü bir Devletle ilgili olması halinde de geçerlidir. Önsorunun kendine özgü yöntemleri, ayrıca diplomatik ajanların, NATO, Birleşmiş Milletler gibi örgütler personelinin özel hükümlerle düzenlenmesi ve nihayet galip Devletler işgal kuvvetlerinin vatandaşlığı konusunda, o Devletler yasalarının uygulanması istisnaları burada da geçerlidir.

\section{Türk Hukukunda Vatandaşlık Çatışmalarnnın Çözümü}

Common law vatandaşlık çatışmalarının çözümünde sürekli olarak ikametgâh ilkesine bağlı kalmıştır. Türk hukukunun, tarihi gelişim içerisinde İngiliz Hukuku kadar tutarlı olmadığı bir gerçektir. Türk hukukunun çifte vatandaşlık çatışmalarının çözümünde tek düze kalmayışının değişik nedenleri vardır. Bu değişik nedenler arasında, Osmanlı Devletinin yapısinın, Cumhuriyet döneminin Devlet yapısından farklı oluşu da sayılmalıdır. Türk hukukunda çifte vatandaşlık konusu dörde ayrılarak incelenecektir. Ayırımın parçaları 1850'ye kadar çifte vatandaşlık, 1850'den Cumhuriyete kadar olan dönem, Cumhuriyetin kuruluşundan $1980^{\circ} \mathrm{e}$ kadar olan kesim ve nihayet 1980 'den sonra olan gelişmeler olarak sıralanmaktadır.

\section{1850 yllina kadar olan gelişmeler}

Irk, dil, din, kültür birliğine sahip olan bireylerin oluşturduğu toplum Ulus (Budun)dur. Uluslararası barışı ve ulusal özgürlüğ̈ü sağlamanın yolu, her Devletin aynı ulusa mensup kişileri vatandaş yapabilmesini gerektirir. Devletin vatandaşları çok uluslu olmamalıdır. Beylik, oymak, boy, klan döneminde geçerli sayılan tek uluslu olma ilkesi gelişmelerin gerisinde kalmıştır. Coğrafî, ekonomik ve siyasî nedenlerle çok ulusluluk kaçınılmaz olmuştur. Devletlerin çok uluslu olması, beraberinde bireylerin çifte vatandaşlığı olgusunu da getirmiştir. Fütuhat ve göç yolu ile kurulan Devletlerin ahali öğesi ulus birliği göstermemektedir. Orta Asya'dan Anadolu'ya göç yoluyla gelen Türk'lerin kurduğu Osmanlı Devleti fetihlerle büyüimüştür. Göç ve fütuhat üzerine kurulmuş olan bir Devletin tek uluslu olması olanaksızdır. Şerî dïzene dayalı ve çok uluslu Osmanlı Devletinin çifte vatandaşlıkla karşlaşması doğaldır. 
Yabancı ufak bir formalite ile müslïmanlı̆̆ kabul etmekte, kendi aslî yatandaşlığinı kaybetmese dahi Osmanlı tebaası olabilmektedir. Ülke'de bulunan gayr-1 müslim tebaa ise, izin almadan yabancı Devlet vatandaşı olabilmektedir. Cizye ve benzeri vergiler ödemek vatandaşlık bağının ölçütü olmaktadır. Müslüman tebaanın vatandaşlığını sınırlayan özel bir düzenlemeye Osmanlı Devleti gerek duymamıştır. Müslüman ahalinin hem Mısır, hem de Osmanlı tebaası olmasi veyahut Fransız koruması altındaki Fas ve Osmanlı vatandaşlığını taşıması olasıdır. Kısaca, 1850 yılına kadar Osmanlı Devleti'nde vatandaşlık sorunları, Devlet anlayışı ile bağdaşmayacak bir karışıklık içindedir.

Islâm şeriatına göre, dünya dariislâm ve darilharp diye ikiye aynlmaktadır. Dariislâm, yani islâm iilkesinde bulunan ahaliden müslümanlar tebaadır. Ülke'de ikamet eden müslïman erkek tebaadan olan çocuk da vatandaşdır. Tâbiiyat bağı feodal düzendeki gibi, ïlke topraklarının üzerinde ikamet eden müslüman kişiler, ülke topraklarının sahibi hükỉmdarın tebaasıdır. Bu sistemin işleyişinin en önemli noksanı, Osmanlı Devletinde, Batı Avrupa hristiyan Devletlerindeki gibi düzenli ve sağlıklı ikametgâh ve şahsî hal sicillerinin tutulmamış olmasıdir.

Ülke'de bulunan gayr-1 múslim tebaa ise, zımnî (reaya) ve harbi diye ikiye ayrılmaktadır. Zımnî ülkede oturan ve cizye olarak adlandırılan vergiyi veren gayr-1 müslim tebaadır. Ius sanguinis esas1na göre, çocuklar babalarının vatandaşlığını alırlar. Burada da, ülke'de ikamet vatandaşlık bağının kurulması için temeldir. PrensDevlet dönemindekine benzer bir durum vardır.

Yabancılar ise, amanlı ve amansız olmak üzere ikiye ayrılmaktadır. Aman çıkartan ve bu aman gereğince ülkede oturan yabancılar mal ve can güvenliğine sahiptir. Buna karşılık aman çıkarmadan ülkeye giren ecnebiler, diplomatik görevliler hariç, esir gibi işlem görme olasslığı ile karşı karşıyadır.

Osmanlı döneminde, yukarıda özetlenen an'asıl tebaa olabilmenin yanında telsik kurumunun da bulunduğu Ahitnamelerden anlaşlimaktadır. 25 Şaban 941 (yani Şubat 1535) yılında Fransa ile yapilan Barıs, Dostluk ve Ticaret Andlaşmașında, Fransız tebaasının "......kendileri zorlanmadan istemezler ve ağızlanyla söylemezlerse Türk yapılmasınlar ve sayılmasınlar......" hükmü getirilmiştir. Aynı Ahitnamenin bir başka hükmüne göre ise, Fransız tebaasının Osmanlı "....memleketinde devaml ve aralıksız on yıl oturmadıça 
cizye, haraç, avadız, kasabiye ödemeye mecbur...." olmadığı hükmü getirilmişti ${ }^{39}$. Bu hükümlerden çıkan sonuç, irade beyanında bulunan Fransızların Osmanlı tebaası olabileceğidir. Telsik'in temel koşulu olan müslüman olma gereğinden Ahitname'de söz edilmemektedir. Bu nedenle, Ahitname'den çıkan sonuç, bir Fransızın gayr-ı müslmin Osmanlı Tebaa'sı olarak telsik'i için 10 yıllık sürenin arandığıdır. Fransa'dan çıkma belgesi getirme zorunluluğu olmadığına göre, bir Fransızın çifte tâbiiyetli olması yolu açıktır.

Telsik'in yanında vatandaşlıktan çıkma kurumunun da Osmanlı Devleti'nde uygulandığı yine andłaşmalardan anlaşılmaktadır. 21 Temmuz 1774 tarihli Küçük Kaynarca Andlaşması md.17/4 hükmüne göre "Terk-i vatan idüp ahar mahallere varmak rağbetinde olanlar temamen mal ve eşyalariyle nakl itmek Devlet-i Aliye'm canibinde merkumune ruhsat virilür...."40. Sözï edilen ruhsat günümüz çıkma belgesi ile karşılaştırılabilir. Osmanlı Devleti değişik metinlerde yer alan münferid hükümlerden bir tâbiiyet yasası yapma becerikliliğini gösterememiştir.

Vatandaşlık yasasının bulunmaması, münferit hükümlerin de dağınık olması ve uyumlı bir Devlet düzeninin bulunmaması, Ülke'de arzu edilemeyecek düzeyde çifte tâbiiyetli bulunmasına yol açmıştır. Çifte tâbiiyetli insanların Osmanlı ülkesinde yarattığı rahatsızlık 1267 (1850) yılından yabancı Büyük Elçiliklere gönderilen Müzekkere'de aşağıdaki biçimde ifade edilmiştir. ".....tebaa-i merkumanin mazhar oldukları menafî̀ ve imtiyazattan istifade eylemek garaz-i masusiyle tebaa-i Devlet-i Aliyye'den birçok eşhas birer suretle istihsal-i himayet-i ecnebiyeye ipdidar eylemekte vatan-1 aslîlerinde dahi kâffe-i tekâlif-i tâbiiyetten kendilerini müstesna tutmaktadirlar"41.

Bu durumun ijlkenin yasalarını uygulamayı ve uilkede iç ve dış güvenliği sağlamayı güçleştirdiği Müzekkere'de anlatılmakta ve "....bu uygunsuzluğun defî zımnında....." çifte vatandaşlığı önleyici hüküm getirilmekte olduğu belirtilmektedir.

39. Metin için bkz. Erim Devletlerarası Hukuk ve Siyasî Tarih Metinleri, Cilt I, Ankara 1935 , s.11 ve 14 .

40. Erim. age., s.129 metin opsiyon hakkına yönelik olarak da yorumlanabilecek biçinnde düzenlenmiştir.

41. Bilâ Mezuniyet Tâbiiyet-i Osmaniyeyi Terkedenler Hakkında IItthaz Edilen Usûle Dair Süferat-1 Ecnebiyeye Gönderilen Müzekkere, Sene 1267, metin için bkz. Unat, Türk Vatandaşlik Hukuku, Ankara 1966, s.1. 
Müzekkere, çifte vatandaşlığı önleme alanında lex fori ilkesini getirmektedir. "............tebaa-yi Devlet-i Aliyyeden her kim âher bir Devletin tâbiiyetine girerse......" ùç ay içerisinde ülke'yi terk etmek zorundadır. Osmanlı tâbiiyeti yanında bir başka Devlet vatandaşl1ğına sahip olan ve fakat ülkede kalmak isteyen çifte tâbiiyetliler yabancı olarak kabul edilmeyecek ve kendilerine ".............kemâkân tebaa-yi Devlet-i Aliyye nazariyle bakılacaktır.....". Bu yoldan, çifte vatandaşlığı olanın vatandaşlıklarından birisinin Türk olması halinde Türk sayılacağı ilkesi 1850 yılından beri, ülke hukukunun bir parçasıdır. 1930 Lahey Sözleşmesi ile uyumlu olan Müzekkere çağdaş Türk vatandaşlık hukuku'nun temellerini atan önemli bir belgedir.

Müzekkere vatanđaşlık çatışmalan sorununa çözüm getirme çabasımı gösteren ilk metindir. Müzekkere Osmanlı Tebaası'nın, kapitülasyonlardan yararlanabilmek için, para ile satın alınma dahil değişik yöntemlerle yabancı Devlet vatandaşlığına girişinin sonuçlarını düzenlemek istemiştir. Böyle uluslararası teamüle uygun olmayan yöntemlerle kazanılmış çifte vatandaşlık sonucunda, hukukî temeli olmayan garip bir durum ortaya çıkmıştır. Düzensiz çifte vatandaşlık niteliğindeki bu durumun sonuçları da düzenli vatandaşlıktan farklıdır. Ingiliz ve Osmanlı vatandaşlıklarına sahip ve Osmanlı ülkesinde ikamet eden kişi, Osmanlı ülkesinde Ingiliz vatandaşı gibi kapitülasyonlardan yararlanmaktadır. Ancak, aynı kişi İngiltere'ye gittiği zaman Osmanlı vatandaşı gibi işlem görmektedir. Kapitïlasyonlardan yararlanmak için verilen vatandaşlık, kural olarak kişiyi Ingiliz pasaportu sahibi yapmamakta ve İngiliz mahkemelerinin uluslararası yetkisine tâbi kılmamakta ve üçîncü iilkelerde İngiliz diplomatik korumasına sokmamaktadır.

\section{1850'den Cumhuriyete Kadar Olan Dönem}

1850 yılına kadar Osmanlı Devleti çifte vatandaşlığın her tïrünün sınırsız biçimde uygulandığı bir ülkedir. Ortaya çıkan çifte vatandaşlığın hukukî statüsüinü kapitülasyonlara ilişkin sözleşmeler düzenlenmiştir. Müzekkere'den istediği sonucu alamayan Osmanlı Devleti, konuyu yasal temellere oturtmak amaci ile 1869 tarihinde Tâbiiyet-i Osmaniyeye Dair Nizamnameyi çıkarmıştır. Sonradan Tâbiiyeti Osmaniye Kanunnamesi denilen bu metin 1851 tarihli Fransız Vatandaşlık Yasasından esinlenerek hazırlanmıştır. Tüm çabalara rağmen, Osmanlı Devleti çifte vatandaşlık kurumunun sakıncalı yönlerine engel olamamıştır. 
1906 yılında çıkarılan Irade-i Seniyye'den çifte vatandaşlı̆̆ın suiistimali sorununun, Tâbiiyet-i Osmaniye Kanunnamesine ră̆men kesin olarak çözümlenemediği anlaşılmaktadır. Sorunu Mǜzekkere'den daha açık düzenleyen Irade-i Seniyye'ye göre, lex fori kuralına kesin uyulacaktır. Ülke'ye ".....avdet ve dühul edenlerin tâbiiyet-i asliye-i Osmaniyeleri sabit oldukta..... tâbiiyet-i muiktesebesine asla iltifat olunmayarak hakkında tâbiiyet-i asliyesi itibariyle Tebaa-i Devlet-i Aliyye muamelesi icra kılınma" öngöriulmüşşür ${ }^{42}$. Bireyin tâbiiyet-i müktesebesini ileri sürerek, kapitülasyonlardan yararlanmak istemesi halinde kendisi derhal yurt dışına çıkarılır.

Irade-i Seniyye çifte vatandaşlık çatışmaları hakkında genel bir sistem getirmemektedir. Tâbiiyeti asliyesi Fransız, fakat tâbiiyet-i müktesebesi Osmanlı olan kişiler açısından vatandaşlık çatışmalarının nasıl çözümleneceği belirtilmemiştir. Vatandaşlıklardan her ikisinin de yabancı Devlet vatandaşlığı olması konusuna değinilmemekte, lex fori uygulamasının istisnalarına yer verilmemektedir.

\section{Cumhuriyetin İlântndan 1980 Yllna Kadar Olan Uygulama}

Müzekker ve İrade-i Seniyye gerçekte vatandaşlık çatışmalarına çözüm getirmeyi erek (hedef) olarak seçmemiştir. Her iki belge de, doğumdan Osmanlı vatandaşı, gayr-1 müslim tebaa'nın çifte vatandaşlık yöntemiyle bağışıklıklardan yararlanmalarını önlemektedir. Osmanlı Devleti aynı dönemde İngiltere'nin çifte vatandaşlık sorunlarını gögüuslemek üzere çıkardığı 1870 tarihli The Naturalization Act örnek alınarak genel bir düzenleme getirememiştir. Tâbiiyet-i Osmaniye Kanunnamesi ise, esasen yetersiz olan hükümleri ile tek başına istenen sonucu verememiştir. Lozan Barış Andlaşmasını arkasına alan Türkiye Cummhuriyeti lâik ve vatandaşlar arasında hukukî statü birliğini öngören bir Devlet yapısını benimsemiştir.

1312 sayılı ve 1928 tarihli Vatandaşlık Yasaşı da ius sanguinis'ten hareket etmiş, istisnaen ius soli'ye yer vermiştir. Yasanın tüm hükümleri göz önüne alındığgnda, o dönemde az olan Türkiye'nin nüfusunu çoğaltmak siyasetinin amaçlandığı gözlenir. Özellikle, Türkiye'nin sınırları dışında, eski Osmanlı ülkesinde otur-

42. Unat, age., s.25. 
makta olan müslüman ahaliden Türkiye'ye gelmek isteyenlere vatandaşlık kazanmada kolaylık sağlamak temel ilkedir. 1312 sayılı yasa da, nüfus arttırmak siyasetini güden her vatandaşlık yasası gibi çifte vatandaşlığa açıktır. Açıkca belirtmemiş olmasına rağmen, 1312 sayılı yasa yurt dışına göçii düşünmemektedir.

403 sayll ve 1964 tarihli vatandaşlık yasası da 1312 sayılı yasada yer alan ilkeleri temelinden değiştirmemiştir. 403 sayılı yasada, 1312 sayll yasanın uygulamasından elde edilen deneyimler göz önüne alınmış, vatandaşlık hukukunun genel ilkelerine daha geniş dïzeyde uyulmuş ve yasanın sistematiği daha çağdaş biçime getirilmiştir. Sistemdeki düzelmeye rağmen, 1312 saylı yasada yer alan Devletin temel siyaseti değiştirilmemiştir. Çifte vatandaşlik kural olarak yurt dışından ülkeye gelen kişilerin ortaya çıkardığı, istisnai bir sorun olarak görülmüştür. Eski Osmanlı topraklarından ülkeye gelen Türk soylu müslüman insanların, çifte vatandaş olup olmadiklarına bakılmaksızın telsik edilmeleridir. Türkiye'den yabancı ülkelere göç $\mathbf{4 0 3}$ sayılı yasanın düşündüğüü bir sorun değildir. Açık hükme bağlanmamış olsa dahi, ortaya çıkacak vatandaşlık çatışmaları lex fori lehine çözümlenir.

\section{1980'den Sonra Çifte Vatandaşlik}

1960'lı yıllardan itibaren Türkiye yoğun biçimde yurt dışına emek ihraç etmeğe başlamıştır. Bu olgu çifte vatandaşliğa Türk vatandaşlık hukukunda yeni bir boyut kazandırmıştır. Devlet yurt dışında ve özellikle eski Osmanlı topraklarında oturan insanların yanında yabancı ülkelere gönderdiği gurbetçileri de düşüinmek zorunda kalmıştır. Bu gelişmenin yasalara, kısmen de olsa yansıması 20 yıl gibi bir zamanı gerektirmiştir.

Yurt dışına gönderdiği insanların ülke'den kopmasını önlemek isteyen Devlet, vatandaşlık yasasını kısa aralıklarla değiştirmiştir. 13.2.1981 tarih ve 2383 saylı yasa, 20.4.1989 tarih ve 3450 sayll yasa, 27.5.1992 tarih ve 3808 sayllı yasa, 7.6.1995 tarih ve 4112 sayılı yasa örnekleri T.V.Y. dört kez değiştirilmiş olduğunu göstermektedir. Buna koşut olarak 1111 sayılı Askerlik Yasası'nda 13.2.1981 tarih ve 2383 sayılı yasa ile çifte vatandaşlığı olanların askerlik durumu yeniden düzenlenmiştir. Aynca Türk Parasının Kıymetini Korumaya ilişkin mevzuatta da değişiklikler yapılmıştır. Çifte vatandaşlığın sonuçlannı düzenlemeye yönelik bu perakende düzenlemeler bir sistemden yoksundur. Değişen koşulların ışı̆̆ı altında ya T.V.Y. yeniden ele alınarak, yasanın ayrı bir bölümünde 
yurt dışında bulunanlar açısından çifte vatandaşlı̆̆ gözönüne alan yeni bir düżenleme yapılmalı veyahut T.V.Y.'den bağımsız yeni bir çifte vatandaşlık yasası çıkarılmalıdır. Bu sonuca, 2709 sayılı 1982 Anayasası'nın 62'nci maddesine dayanarak da ulaşılabilir. Aslen. Türkiye Cumhuriyeti vatandaşı olan insanların, kökenleri ne olursa olsun ana vatanla bağlarının kopması başka türlü önlenemez.

a) Düzenli Çifte Vatandaşık Çatışmaları

Vatandaşlık çatışmalarına özgü bir hüküm T.V.Y.'nda yer almadığına göre 2675 sayılı DHH yasası md.4 hükmü gözönüne alınacaktır. Ancak, yasaların çatı̧̧masındaki ulusal yasa (millî kanun) ilkesi ile vatandaşlık çatışmalarındaki çözüm arasında parallelik ofduğu 1930 tarihli Lahey Sözleşmesinden (Konvansiyonundan) anlaşılmaktadır.

2675 sayılı DHH yasası md.4/b hükmüne göre, "birden fazla Devlet vatandaşlı̆̆ına sahip olanlar hakkında, bunların aynı zamanda Türk vatandaşı olmalan halinde Türk hukuku" uygulanır. 1930 Lahey Sözleşmesini gözönüne alarak hükmü uygularsak, Türk vatandaşlığı yanında bir ikinci vatandaşlığa sahip olanlar, Türk sayılır sonucuna varırız. Türk hukukunda da, lex fori kuralına yukarıda genel inceleme sırasında yer alan tüm istisnalar uygulanır. Önsorun, 24 Aralık 1984 tarihli Resmî Gazete'de yayınlanmış olan Diplomatik İlişkiler Hakkında Viyana Sözleşmesinden doğan istisnalar, uluslararası örgütlerin durumu, 1930 Lahey Sözleşmesine ekli çok vatandaşlığı olanların askerlik yükümüne ilişkin hükümler, işgal kuvvetlerinin özel durumu istisnalan Türk hukukunda da geçerlidir.

Çifte vatandaşlığı olan bireyin hakkınt kötüye kullanmasından Osmanlı Devleti döneminde yakınılmış ve lex fori uygulamasına rağmen kişinin strf kapitülasyonlardan yararlanmak için aslî vatandaşlı̆ı̆ının yanında ikinci bir vatandaşlık aldığı vurgulanmıştır. Çifte vatandaşlığın verdiği haklardan yararlanmak isteyen, aslen Türk vatandaşı olan bireyin yurt dışına gönderileceği, daha önce sözü edilmiş Müzekkere ve İrade-i Seniyye'de belirtilmiştir. Osmanlı Devletinin bu anlayışı iki yönden vatandaşlık hukuku ilkeleri ile bağdaşmamaktadır.

Önce, vatandaşlık hukuku alanında bireyin hakkını kötüye kullanması sorunu üzerinde durulmalıdır. Vatandaşlık egemen Devletin iradesine dayanarak kurulan bir bağdır. Devletin egemenliğine dayanan bir konuda bireyin hakkını kötïye kullanmasının yeri yok- 
tur. Bireyin vatandaşlık hakkını kendi iradesi ile fesih hakkı yoktur. Devlet çkma, çıkarma, kaybettirme, vatandaşlığa alınmanın iptali kurumlarına dayanarak, daha önce vermiş olduğu hakkı geri alır. Devletin iradesi ile kurulmuş olan bağın, Devletin tek taraflı irade beyanı ile geri alınmasıđır. Hakkın kötüye kullanılması Devlet açısından söz konusu olabilir. Osmanlı Devleti, çifte vatandaşlığı alan bireyin değil, ona o vatandaşlığı veren Devletin hakkını kötüye kullanđığını önceleri görememiştir. 11 Ocak 1869 tarihli Tâbiiyet-i Osmaniye Kanunnamesi'nin beşinci maddesi konu ile ilgili olarak bir adım ileri gitmiştir. Buna göre kişi "Devlet-i Aliyyeden mezun olmaksızın tâbiiyeti Ecnebiyeye girer ise, işbu tâbiiyeti cedidesi keenlemyekûn"dur. Aynı madde bir ikinci adım daha atmakta ve günümüz çıkma belgesinin temelini atmaktadır. Bir şahsın, Osmanlı tâbiiyetinden çıması" mutlaka irade-i seniyye üzerine verilecek bir senede muallak olacaktır."

İkinci nokta, çifte vatandaşlı̆̆ olan bireyin yurt dışına ikametgâhını taşıma veya ïlkeye geri dönmeme gibi bir cezaya çarptırılmasıdır. Vatandaşlık yasaları cezaî hükümleri içeren mevzuattan sayılmazlar. Devlet beğenmediği kişinin vatandaşlık bağınt, kendisine yasaların tanımış olduğu ilkeler çerçevesinde sona erdirir veya diğer bir deyişle fesheder. Vatandaşlık bağı sona eren kişinin ikametgâhını yurt dışına taşıması, mallarının tasfiyesi veya ủlkeye girişinin yasaklanması gibi cezaî nitelik taşıyan hükümlerin vatandaşı̆̆̀n genel ilkeleri ile bağdaşmadığı bir gerçektir. Tâbiiyet-i Osmaniye Kanunnamesi md. 5 ve 6,1312 sayll T.V.Y. md.8, 12 belirtilen yönde cezaî hükümler taşımaktadır. 403 sayılı T.V.Y. cezaî nitelik taşıyan bu hükümleri gözönüne almayarak çağdaşlaşma yolunda önemli bir adım atmıştır.

Yurt içinde geçerli olan Türk vatandaşlan arasında hukukî stàtü eşitliği, yurt dışında bulunan Türkler açısından da varlığını sürdürmelidir. Yurt dışında bulunan Türk vatandaşlarını çalışanlar ve çalışma dışındaki nedenlerle bulunanlar diye ayırmak, Anayasa md.62'nin yaptığı gibi, yersizdir. Yurt dışında çalışma dışındaki bir nedenle bulunanlar, Anayasa md. 62 kapsamına girmeyen bir grup oluşturmamalıdır. Gerçekte Devletin yurt đışında bulunan tüm Türklerin, çifte vatandaşhı̆ı olanlar ve sığınmacılar dahil anavatandan kopmalarını önleyecek önlemleri alma yükümü bulunmalıdır. Devlet bu yükümü yerine getirirken esnek davranmalıdrr.

Kişinin vatandaşlıklarından hiçbirisinin Türk olmaması haline ilişkin bir hüiküm Osmanlı mevzuatında yer almamaktadır. Örneğin 
bir Brezilya vatandaşının, sırf Kapitülasyonların getirdiği haklardan yararlanmak için Rus veya Ingiliz vatandaşlığını da alması Osmanlı Devleti tarafından gözönüne alınmamıştır. Bu halde de, ikinci vatandaşlık hükümsüz sayılmalıdır.

İlgilinin vatandaşlıklarından hiçbirisinin Türk vatandaşlığı olmaması halinde, 2675 sayıl DHH yasası md. 4/c'ye göre "birden çok vatandaşlığı olup, aynı zamanda Türk vatandaşı olmayanlar hakkında daha sıkı ilişki halinde bulundukları Devlet Hukuku uygulanır". Bu hüküm vatandaşlık hukuku alanında da uygulanacak olursa, hiçbir ayırım yapmadan kişinin en sıkı ilişki halinde bulunduğu Devlet vatandaşlığının seçilmesi gerekecektir. Çifte vatandaşlığa sahip kişinin ülkesinde ikamet ettiği üike vatandaşlığına bir öncelik tanınmamaktadır. Kişinin en sıkı ilişki halinde bulunduğu Devlet vatandaşlığı, yargıcın takdirine dayanarak bulunan ve objektif olmayan bir seçimdir.

Ulusiararası hukukun aradığı, insanların objektif ölçütlerle Devletler arasında taksimidir. Gerçek vatandaşlık ilkesinin, yani en sıkı ilişki halinin uygulanmasından önce, kişinin ikametgâhı veya mûtaden bulunduğu Devlet vatandaşlığına öncelik tanınmalıdır. Bu durum, 1930 Lahey Sözleşmesinin geniş yorumu ile ve Common $l a w^{\prime} l a$ aynı paralelde olacaktır. Uygulamada, sağlam ve inandıncı olan ikametgâh ve mûtaden bulunulan Devlet vatandaşlığına dayanarak verilecek kararların ülke dışında da hüküm ifade edeceği bir gerçektir.

Kişinin vatandaşı olduğu her iki Devlet ïlkesinde de ikamet etmemesi veyahut mûtaden bulunmaması halinde, 2675 sayılı DHH yasası md.4/c'de öngörülen gerçek vatandaşlık araştırılmalıdır. İkametgâh, mûtaden bulunulan yer, iş iliş̧kileri, seçimlerde oy verilen yer, dil, öğrenim, ailenin bulunduğu yer, banka hesabı, taşınmazlar, kambiyo senetlerinin düzenlendiği gibi yer tüm ilişkiler demetine bakarak vatandaşliklardan birisi seçilecekiir. Yargıç seçimi yaparken elden geldiğince objektif olmak durumundadır. Bu uygulamalarda da daha önce belirtilmiş olan tüm istisnalar geçerlidir.

\section{b) Fiili çifte vatändaşlik çatışmalan}

Vatandaşlık bağı üç öğeyi içeren bir bütündür. Biçimsel yapt (vatandaş olma koşulları), özdeksel içerik (maddî muhteva-hukukî 
statii) ve gerçeklik ilkeși (soy birliği) ìç öğeyi oluşturmaktadır ${ }^{43}$. Bireyin yurt dışına göç etmesi ile vatandaşlık bağının bütünlüĭgu bozulmaktadır. Yeni bir vatandaşlık kazanmadan yurt dışına göçen bireyin biçimsel vatandaşlığı tekniğini korumakta, fakat özdeksel vatandaşlığı çiftleşebilmektedir. Bir yanda biçimsel vatandaşlığına sahip olduğu Devletin tanıdığı hukukî statỉ, diğer yanda göç ettiği Devletin tanıdığı hukukî durum yer almaktadır.

Birey çifte özdeksel vatandaşlığa sahiptir. Göç ettiği ülkenin kendisine, o ülke vatandaşınınkine eşit hukukî statiu tanıması halinde, üstïn veya yeni özdeksel vatandaşlık doğmaktadır. Göç ettiği Devlet ile birey arasında hukukî ve siyasî bağ oluşmaktadır. Bireyin göç ettiği Devletin vatandaşlarından farkı siyasî haklardan yararlanma alanında, özellikle kendisini göstermektedir. Buna karşılık, özdeksel vatandaşlığın yardımı ile, Avrupa Birliğine üye Devletlere vize yükümü olmadan seyahat edebilmektedir. Bu olanaktan birliğe üye olmayan İsviçre'de de yararlanmaktadır.

Üstün özdeksel vatandaşlık kendi kapsamına giren konularda, süresiz çalışma ve ikamet hakkını veren ülkenin diplomatik korumasına da, sınırlı bir biçimde de olsa yer vermektedir. Bu koruma, özellikle sosyal güvenliğe giren konularda kendisini göstermektedir. Ayrıca, üstün özdeksel vatandaşlik veren Devlet bireyi, suç işlemesi halinde vatandaş gibi işleme tâbi tutmaktadır. UUlke dişına çıkarma ilke değildir.

Ưstün özdeksel vatandaşlı kişileri vatandaş (telsik) yapmadan uygulanan geçici bir assimilasyon aşamasıdır. Devlet, vatandaşlığın gerçekliği ilkesinin (soy ve kültür birliğinin) (Volkszugehörigkeit) olmadığı zaman bir tür staj devresi araya koymaktadır. Bu staj devresi en çok iki veya üç kuşak sürmektedir. Devletin amacı üstün özdeksel vatandaşlik yoluyla gelen yabancının kendi ahalisinin kültiurüne bağlanmasıdır. 'Süre geçmesi ile soy birliğine ulaşılamayacağı açıktır.

Fïilî vatandaşlıktan doğan vảtandaşlık çatışmalarında olaya taraf Devletler açısından üstün özdeksel vatandaşlık belli sınırlarla öncelik taşımalıdır. Birey hayatını, göç ettiği ve vatandaşına temsil edildiği ülkede kazanmaktadır. Iradesi ile gittiği ülkeden süresiz çalışma ve ikamet izni almıştır. Gittiği ülkenin telsik koşullannı yeri-

43. Vatandaşlı̆̆ın uç ơğesi hk. bkz. Göğer, Türk Tábiiyet Hukuku, Ankara 1979, s.6. 
ne getirmekte, fakat vatandaşlığın gerçekliği (soy birliği) olmadığından biçimsel vatandaşlık gecikmektedir.

1930 Lahey Sözleşmesi kapsamına fiilî çifte vatandaşlıktan doğan çatışmalar girmemektedir. Konvansiyonun yapıldığı dönemde fiilî çifte vatandaşlık günümüzdeki düzeyde önem taşımamıştır. Konunun karmaşık niteliği, hakkında konvansiyon yapılmasını güçleştirici bir etmendir.

Fiilî çifte vatandaşlık halinde, ïstün özdeksel vatandaşlığa tanınan önceliğin sınırı konusu ad hoc kararlarla bulunacaktır. Yabancı Devletten süresiz çalışma ve ikamet izni alan birey, aslî vatanından derhal kopmamaktadır. Kopma yavaş yavaş gerçekleşmektedir. Gidilen yabancı Devletin assimilasyon siyasetine karşı koyabilmek için, bireyin aslî vatandaşı olduğu Devletin özveride bulunması ve bireye daha geniş hukukî ve ekonomik olanaklar getirmesi gereklidir.

Üçüncü Devletler açısından fiilî çifte vatandaşlıktan doğan çatışmaları ayırıma tâbi tutarak incelemek yerindedir. Uçüncü Devletin, üstün özdeksel vatandaşlığı tanıyan Devletle aynı ekonomik ve siyasi birliğin (ömeğin Avrupa Birliği'nin) üyesi olması ilk haldir. Bu halde sorun ad hoc çözümlenecektir. Genel kural, istisnalarla donatılmış aslî vatandaşlık lehine öncelik olmalıdır. Ancak, bu genel kuralın herhalde geçerliği çok şüphelidir.

Aynı ekonomik ve siyasî birliğe üye olmayan üçüncü Devletler açısından biçimsel vatandaşlık önde yer almalıdır. Ủçüncü Devletler edimli (fiilî) gerçekleri inceleyerek bireyin çıkarlarını kollamak zahmetine, kendileri için önemli bir siyasî veya ekonomik çıkar olmadıkça katlanmamaktadır.

Karışık olan çifte vatandaşlıktan doğan çatışmaların çözüimü alanında gerçekçi yöntem ikametgâh Devleti vatandaşhı̆̆ına, istisnalar saklı kalma koşulu ile öncelik tanımadır. İkametgâh kavramı üzerinde ve istisnalar konusunda oybirliği olmadıkça, uygulaması kolay gibi görünen yöntem de çıkmaza girecektir.

\section{SONUÇ}

Cumhuriyet'le birlikte vatandaşlar arasında hukukî statï eşitliğgi getirilmiş ve Osmanlı dönemindeki kargaşadan kurtulunmuştur. Cumhuriyetin getirdiği üniter Devlet yalnızca düzenli çifte vatan- 
daşlığa, 1312 saytlı T.V.Y. olanak tanıdığı dïzeyde göz yummuştur. Çifte vatandaşlığın türleri diye bir konu dönemin Türk vatandaşlık hukukunda bulunmamaktadır. Osmanlı Devletinin mirası niteliğindeki yurt dışında bulunan Türk soyluların ülkeye gelişi 2510 sayılı ve 14.6.1934 tarihli Î́skân Yasası ile düzenlenmiştir. Yurt dışına göç zaten az olan nüfus nedeniyle Türkiye için söz konusu değildir.

1960'h yıllarda Cumhuriyetin kuruluşunda benimsenmiş olan ilkeler ile ortaya çıan fiilî durum arasında uyumsuzluk gözlenmiştir. İk değişiklik Türkiye'nin artan nüfusu ve işsizliği kısmen olsun dengelemek için yurt dışına insan göçüne izin vermesidir. İkinci değişiklik, Türk soyluların Türkiye'ye çalışmak için gelmeleri ve çalışma hukuku alanında vatandaşa temsil edilmeleridir. Üçüncü gelişme ise, Türk soylu olmayan insanların Türkiye'ye göç etmelerine ve kaçak olarak çalışmalarına hoşgörü ile bakılmasıdır.

Bu karmaşık durumu dengelemek için Devlet perakende yasa değişiklikleri yapmış veya münferid yeni yasalarla kısmî düzenlemelere gitmiştir. Durumu halen düzenli biçimde kontrol edemeyen Devlet, ülke'de kaçak çalışan yabancıların statïsünü gösterecek, fakat yine kısmî nitelikte yeni bir yasa yapma hazırlığı içerisindedir. Perakende düzenlemeler yerine genel, toplu ve sistematik tek bir yasa çıkarılmasının daha yerinde olacağı açıktır.

Göç olayı daha uzun bir zamana süreceğine göre, Türk Devleti kapsamlı ve tutarlı sistematiği bulunan tek bir "Ozdeksel Vatandaşlık Yasası" çıkarmalıdır. Özdeksel vatandaşlık yasası adı seçilen amaç doğrultusundadır. Bu yasanın iki amaçı olmalıdır. Önce, yabancı Devlet vatandaşına hukukî statï bakımından eşit olan ve o ïlke'de mûtaden bulunan Türklerin, en azından hukuken vatandaşlıktan tamamen kopmaları önlenmelidir. Fiilî çifte vatandaşlığı bulunan Türk'ün, yabancı Devletin assimilasyonuna hukukî set çekerek, vatandan tamamen kopmasını önleme çabasıdır. Hukukî setin tek başına yeterli olamayacağının bilinci içerisinde bulunulmalıdır. İkinci amaç, Türkiye'ye göç eden yabancıların önce, yavaş yavaş fiilî çifte vatandaşlık aşamasına ulaştırılmasıdır. Bu yabancıların, ikinci veya üçüncü kuşakta assimilasyonunu gerçekleştirip Türkiye'ye kazandırılmasıdır.

Özdeksel vatandaşlık yasasının birinci bölümünde genel hüikümler yer almalıdır. Çifte vatandaşlık halleri, ülke dışında ikamet ve mûtaden bulunma, ülke'den yabancının süresiz ikameti, süresiz 
ikamet ile çalışma izni arasında bulunan farklar, Türk soylu yabancı kavramı, karşılıklı muamele, mukabele-i bilmisil, vatandaşlık açısından hakkın kötiiye kullanılması, sı̆̆ınmacıların fiilî çifte vatandaşlık durumlanı genel hükümlerin konuları arasında yer almalıdir.

İkinci bölümde değişik çifte vatandaşlık halleri ele alınmalıdır. Bölümün ilk faslını düzenli çifte vatandaşlık konusu oluşturmałıdır. Düzenli çifte vatandaşlık nesep bağından doğabilir. Çifte vatandaşlığın doğabilmesi için ana ve babanın irade beyanlarına gerek olup olmadığıdır. Telsik alanında bir yenilik gereklidir. Düzenli çifte vatandaşlı̆ıı arada sırada uygulanan türlerinden onaylı çifte vatandaşlığa yer verilmelidir ${ }^{44}$. Yabancı Devlet vatandaşlığını kazanmış veya kazanabilecek olan Türk, Türk vatandaşlığından ayrılmama koşulu ile Türk Devletinden çıma belgesi istemektedir. Onaylı çifte vatandaşlık halinde verilecek çıma belgesi T.V.Y. md.22'deki çıkma belgesi ile eş değerde olmalıdır.

İkinci bölümün ikinci faslı, fiilî çifte vatandaşlık halini düzenlemelidir. Fiilî çifte vatandaşlığı olan ve yurt dışında oturan Türklerin hukukî statüleri, düzenli çifte vatandaşlığı olan Türklerin hukukî statïleri ile, istisnalar dışında eşit hale getirilmelidir. Fiilî çifte vatandaşlığı olan ülke'deki yabancı Devlet vatandaşlarına ise, milletvekili olma gibi istisnalar đışında vatandaşlara eşit hukukî statü sağlanmalıdır. Tüm fiilî çifte vatandaşlık konusunun can alıcı noktalarından birisi hakkın kötẗye kullanılmasıdır. Yasa gerek bireyin, gerek yabancı Devletlerin hakkın kötïye kullanılması kurumundan yararlanmasını önlemelidir. Örneğin, Yunanistan'ın kendi ülkesine yerleşmiş olan ve Türkiye'ye geri dönme niyeti olmayan rum ortodoks dinine mensup kişilere vatandaşlık vermemesi ve bu kişilerin yapay olarak halen Türk vatandaşlığını korumaları hali örtülü (fiilî) çifte vatandaşıık olarak sayılmamalıdır. Bunun yanında, rum ortodoks dinine mensup Kıbrıs Cumhuriyeti vatandaşının da fiilî çifte vatandaşlığa sahip olabileceği göz önüne alınmalıdır. An'asıl Türk vatandaşı olan sığınmacılatın da fiilî çifte vatandaşığı olan kişiler arasında sayılmaları yerindedir. Fiilî çifte vatandaşlık alanında hakkın kötüye kullanılması da, ikinci bölümüin üçüncü faslı olmalıdır.

44. Delbrijck yasası olarak isimlendirilen onaylı çifte vatandaşlık hali 1913 tarihli Alman Vatandaşlik Yasast md.25/2 tarafından düzenlenmiştir. Bu konuda bkz. Yörïk, Devletler Hususî Hukuku, Kitap 1, Giriş-Tâbiiyet, s.86; Schaetzel, age., s.213; Wolff, age., s.41. 
Olası yasanın üçüncü bölümünde, ortaya çıkacak vatandaşlık çatışmalarının çözümlenmesi ele alınmalıdır. Düizenli çifte vatandaşlık açısından lex fori ilkesinin uygulanması kısmen haklı görülebilir. Fîilî çifte vatandaşlık alanında lex fori'nin yerine ikametgâh veya mûtaden bulunulan yer ilkesi getirilmelidir. Ancak, ister lex fori, isterse ikametgâh ilkesi öncelik taşısın getirilecek istisnalar ile kuramların yanlıs yönleri düzeltilecektir. İstatisnalar konunun en önemli yönüidür. Illgilinin vatandaşlıklarından hiçbirisinin Türk vatandaşlığı olmaması halinde önce ikametgâh vatandaşlığına, sonra gerçek vatandaşlık ilkesine yer verilmelidir. Önsorun, güvence (teminat), emeklilik, miras, ölüme bağlı tasarruf, kişi halleri, ülkeye giriş ve çıkış, vergi istisnalan, muvazzaf askerlik hizmeti yüküimünden bağışıklık halleri, banş döneminde ve savaş döneminde olmak üzere ayn ayrı düzenlenmelidir. Birey, yabancı Devlet tarafından tutulan ve kendisine tebliğ edilen sicil örneklerini Türk makamlarına iletmek yükümï altına sokulmalıdır. Çifte vatandaşlığ1 olanlar hakkında Türk mahkemelerinin Uluslararası yetkisi yeniden düzenlenmelidir. Tüm bu düzenlemelerde Devlet sinırlı da olsa özveride bulunmalı ve bireylerin çıkarlarına öncelik tanımalıdır. Farklı bir tutum, amacın gerçekleştirilmesini güçleştirecektir.

Çıkanlması önerilen yasanın dördüncü bölümünde, fuilî vatandaşık halinde eşin ve çocukların vatandaşıklannın etkilenişi ve hukuk̂̂ statüleri saptanmalıdır. Burada ikinci ve üçüncủ kuşak insanlar düşünülmelidir. Erek, bu kişilerin Türkiye ile olan bağlarının tamamen kopmasını önleyecek hukukî zemini yaratmaktadır. Sığınmacılann eşlerinin ve çocuklarının da kollạnması ve ülkeden kopması önlenmelidir.

Beşinci bölüm, konuya ilişkin özel bir vatandaşlık dairesi kurulmasıdır. En az Genel Müdürlük düzeyinde olması gereken bu dairede her tür çifte vatandaşlık halinin ve Türkiye'de ikamet eden yabancıların sicilleri çağdaş sistemlerle tutulmalıdır. Perakende iş gören, düzenli kayıtları bulunmayan ve çoğu kez kırtasiyeciliğe boğulmuş olan konsolosluklar devre dışı bırakılmalı, çifte vatandaşlığ olan kişinin muhátabı yalnızca bu daire olmalıdır. Çifte vatandaşlığı olanların askerlik işlerine ilişkin kararlar da bu özel dairenin yetkisine sokulmalıdır.

Önerilen altıncı bölüim, çeşitli hükümler başlığını taşımalıdır. Özdeksel vatandaş̧ı̆ğın kanıtlanması, yargı yolu, geçici hükümleri içermelidir. 